(3. $=5$ a

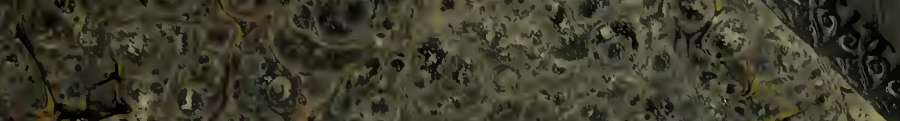

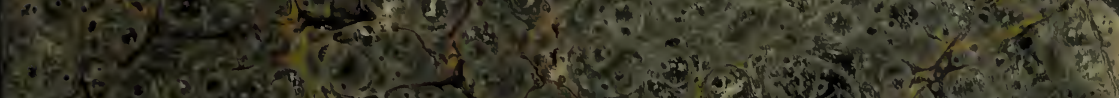

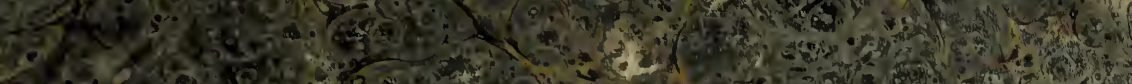

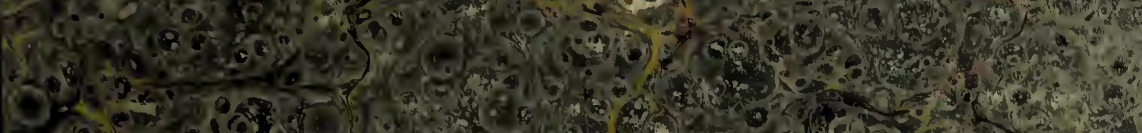

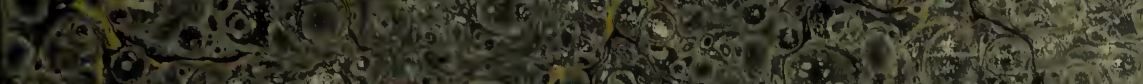

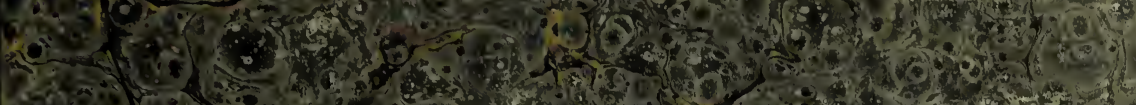

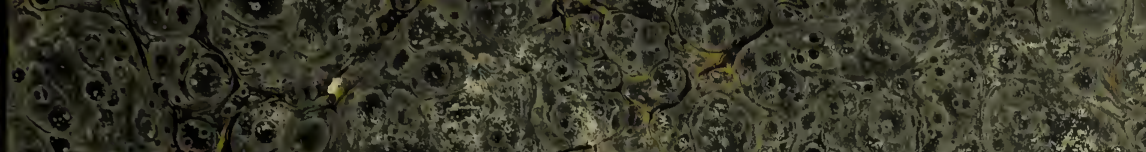

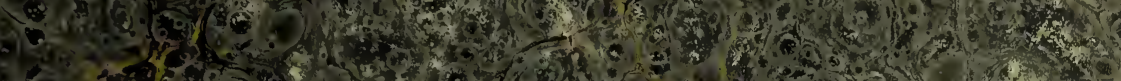
25.3.0.

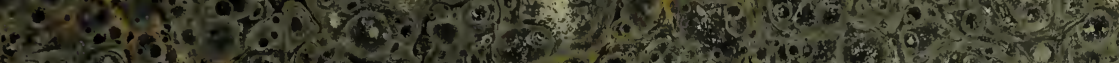

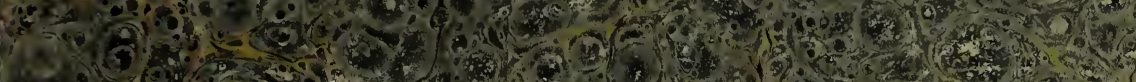
Q 2) 8 .

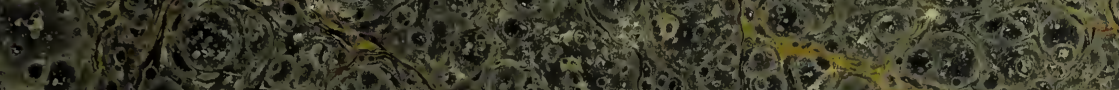
a do

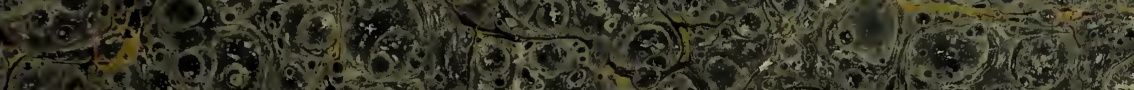

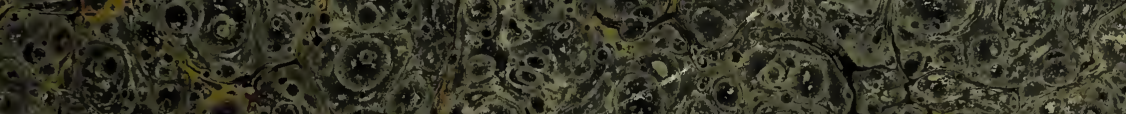
3.

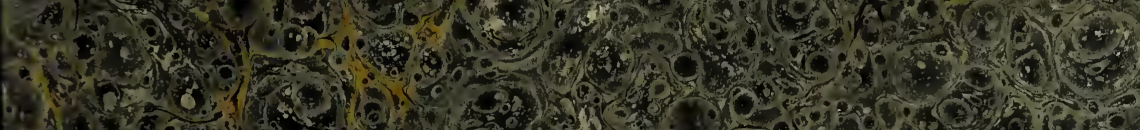

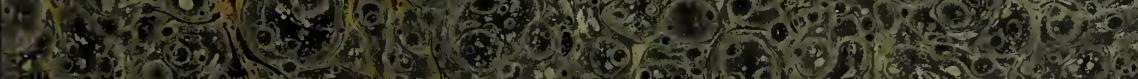
3.5.

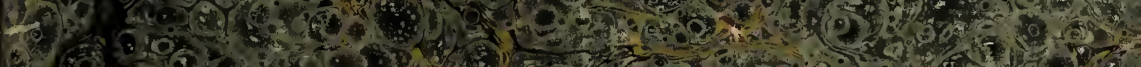
5.

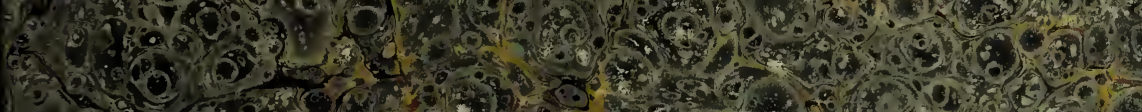

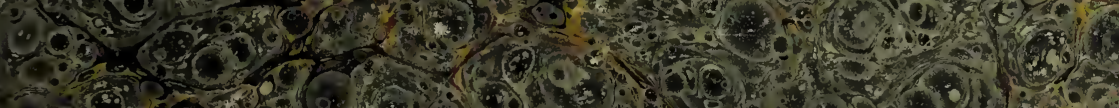

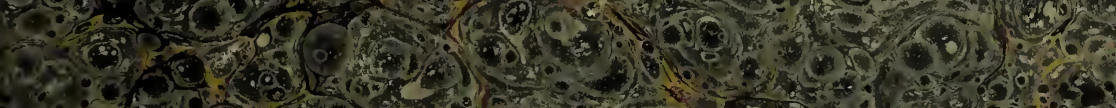

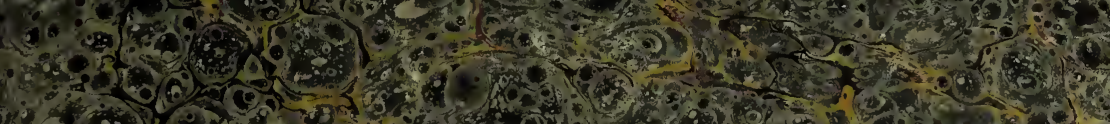

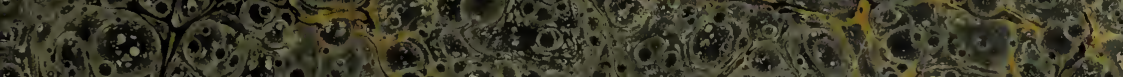
Al

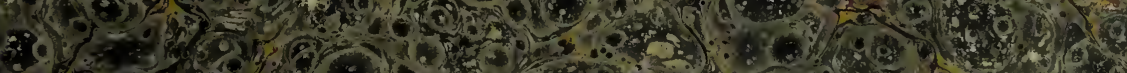

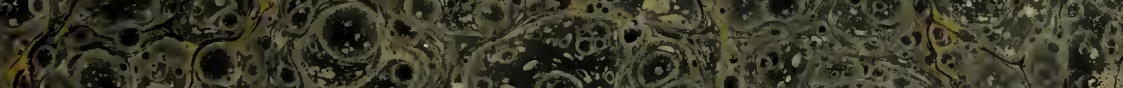
(10.3) a)

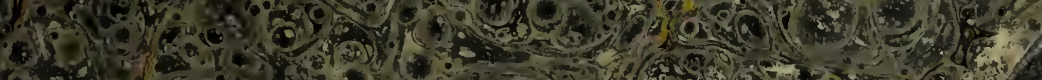

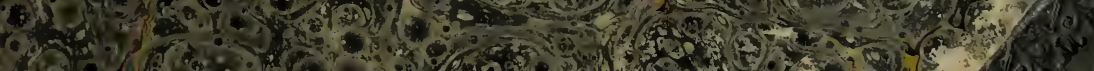

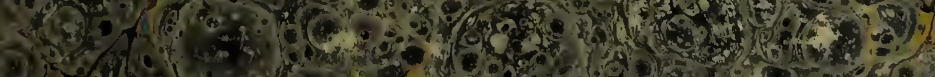


3 
<smiles>c1ccccc1</smiles> 







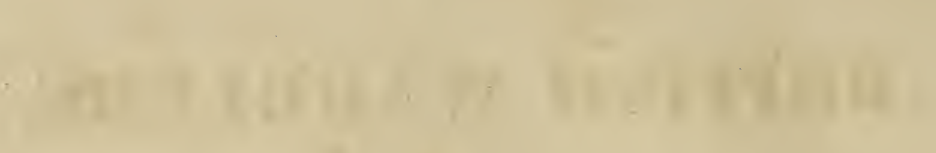




\section{SYLVIA.}

SYLVIA. Bill straight, weak, slender; nostrils obovate, a little depressed; tongue cloven; middle-toe connected underneath to the outer one at the base.

The British species belonging to this interesting genus are chiefly Birds of Passage, visiting this country in Spring, and leaving it again in Autumn; several of these are deservedly esteemed as the finest songsters of all the feathered race; the Nightingale, in particular, has the sweetest and most pleasing note of any bird at present known. It has been generally supposed that they are very difficult to preserve in confinement; but $I$ have succeeded well in keeping several of the most interesting species through several Winters in perfect health, and many of them are in full song all the Winter; and I have not the least doubt but all the species might be kept without difficulty in the way I have practised.

They will succeed very well in a warm room in Winter, or, if convenient, any part of a hot-house would suit them admirably; but they require a little fresh air when the weather is mild; they might be preserved in cages, either separately, or several together; or in a small aviary, where all the species might be intermixed. In the latter manner mine are kept at present. The temperature of the room where they are, ought never to be much 
below temperate, though some of the kinds do not mind a slight frost. The species that I have found suffer most from cold, are, S. Rubetra, S. Phonicurus, and S. hortensis; the Nightingale (S. Luscinia) is not near so tender as these; S. cinerea, S. Sylviella, and S. atricapilla, scarcely seem to mind the cold at all.

In a wild state, the species of this genus feed almost entirely on insects and fruit, but in confinement they may be taught to feed on several other things; but the more insects they have given them the better; and I believe it is impossible to keep them in perfect health without a frequent supply. The food that I find agree with them best for a constancy, is, an equal proportion of bruised hempseed and bread, mixed up in the following manner: I first put some hemp-seed in a little pan, and pour some boiling water on it; then, with a stick flattened at the end, I bruise it as fine as possible, and add the same quantity of soft bread, which must also be bruised up with it, so that the oily milk from the seeds may be mixed with the bread, till it is of the consistence of a moist paste: of this mixture they are all very fond; but it should be mixed up fresh every day, particularly in Summer, or the stale food will injure their health, and make them dislike it altogether. I also give them a little boiled milk and bread for a change, and some fresh raw meat cut in small pieces; some of the species like the fat best, but the greater part prefer the lean. In Winter, when insects are scarce, I occasionally treat them to the yolk of an egg, boiled hard, and then crumbled small; this partly answers the purpose ; but it is a good plan to have a stock of insects in store, to supply them with a few every day, which keeps them in good health, and makes them sing more melodiously.

A supply of some sorts of insects is easily preserved for the Winter. The large species of Flies may be caught in great abundance in Autumn; 
particularly the Musca tenax, which, at that season, are very plentiful on the Dahlias, French and African Marygolds, and other plants belonging to the Composite. Musca vomitoria is also plentiful on the Ivy, when it is in flower; of those two species large quantities may be caught, and dried for the Winter; they only require to be put loosely in a paper bag, and to be hung up in a dry room, so that they do not get mouldy; when they are given to the birds, a little boiling water must be poured on them, which softens them; and the birds are as fond of them as if they were alive. The common maggots from decayed meat might also be saved for them, in large quantities, by collecting them late in Autumn, and putting them in a large pot, or pan, in dry mould, and then keeping it in a cool dry place, will preserve them all the Winter; when a few may be given to the birds as often as the stock will allow of it. If kept in too warm a place, they will turn quickly into the pupa state, and the flies will soon come out of them, and, by that means, the stock will soon diminish; though the birds like them as well or better in the pupa state.

Some fine gravel must also be kept continually in their cages; as the birds of this genus eat a great deal of it, and will not continue in good health without a constant supply. They are also very fond of washing often; so that a pan of water, or something large enough for them to get into, should be kept constantly at the bottom of their cage.

These birds, when in confinement, are very restless at the seasons of their usual migration from one country to another; at the time that they are leaving this country in Autumn, about twice during the Winter, and again when they are returning in Spring. From their agitation at various times in Winter, it may be concluded, that they visit more than one country, after their departure from this; it is very curious to see them, when in that state; their restlessness seems to come on them all at once; 
and, generally, in the evening; when they are setting, seemingly, quite composed, they start up suddenly, and flutter their wings; sometimes flying direct to the top of the cage, or aviary; at other times, running backwards and forwards on their perches, continually flapping their wings, and looking upwards all the time; nor will they notice any thing that is going forward, as long as they continue in that state, which lasts for an hour or two at each time. By their always wishing to fly upwards, it may be supposed, that, when they first take their flight, they mount direct upwards to a great height, so that they can direct their course the better, by seeing the way clear all around them: their agitation generally lasts on them about a fortnight; sometimes more, and sometimes less; in the Spring it seems strongest on them; at that season, they will sometimes flutter about the whole of the night, and sleep a great part of the day.

The species, of which Figures are given in this work; are all I possess at present; but, besides these, I have kept in cages, for several years, the Black-cap (S. atricapilla,) and the lesser Whitethroat (S. Sylviella.) 1 also kept the Chiff-chaff (S. Hippolais) for a considerable time; it then flew away. As I am still anxious to increase my collection, I would willingly exchange any sorts of which I have duplicates, for others that 1 do not possess. Wild Birds, fresh caught, I would prefer; the species I most wish for, are, S. Locustella, S. salicaria, and S. Dartfordiensis.

The best method of catching the birds of this genus, is with the common Nightingale trap, baited with living insects When they are first canght, they must be fed with insects, or fruit, according to their species; but they will soon learn to eat the other food, by sticking insects, or fruit, in it, so that they once taste it; if they are put in with tame birds, they will sooner get reconciled to their confinement; or, if two or three wild ones are put together, they will 
do much better than a single one. When first caught, the cage in which they are kept should be darkened, all but a little light near their food, or they will be apt to beat themselves very much, and not be so likely to do well; it is, certainly, a good plan to keep several together; particularly in Winter, as they will set close together on their perch at night, and, by that means, keep each other warm.

Young birds of any of this genus, may be bred up by hand, if the nests are taken as soon as the birds are fledged; they may be fed on the same kind of food recommended for the old ones, feeding them as often as they chirp for food, and giving them as much as they will take readily each time, not forgetting to let a drop or two of clean water fall into their mouths frequently; by neglecting this, I believe to be the only reason that so few people can rear young birds. Those bred in this way are very tame and familiar; but I do not think them so hardy as those that are caught wild. 




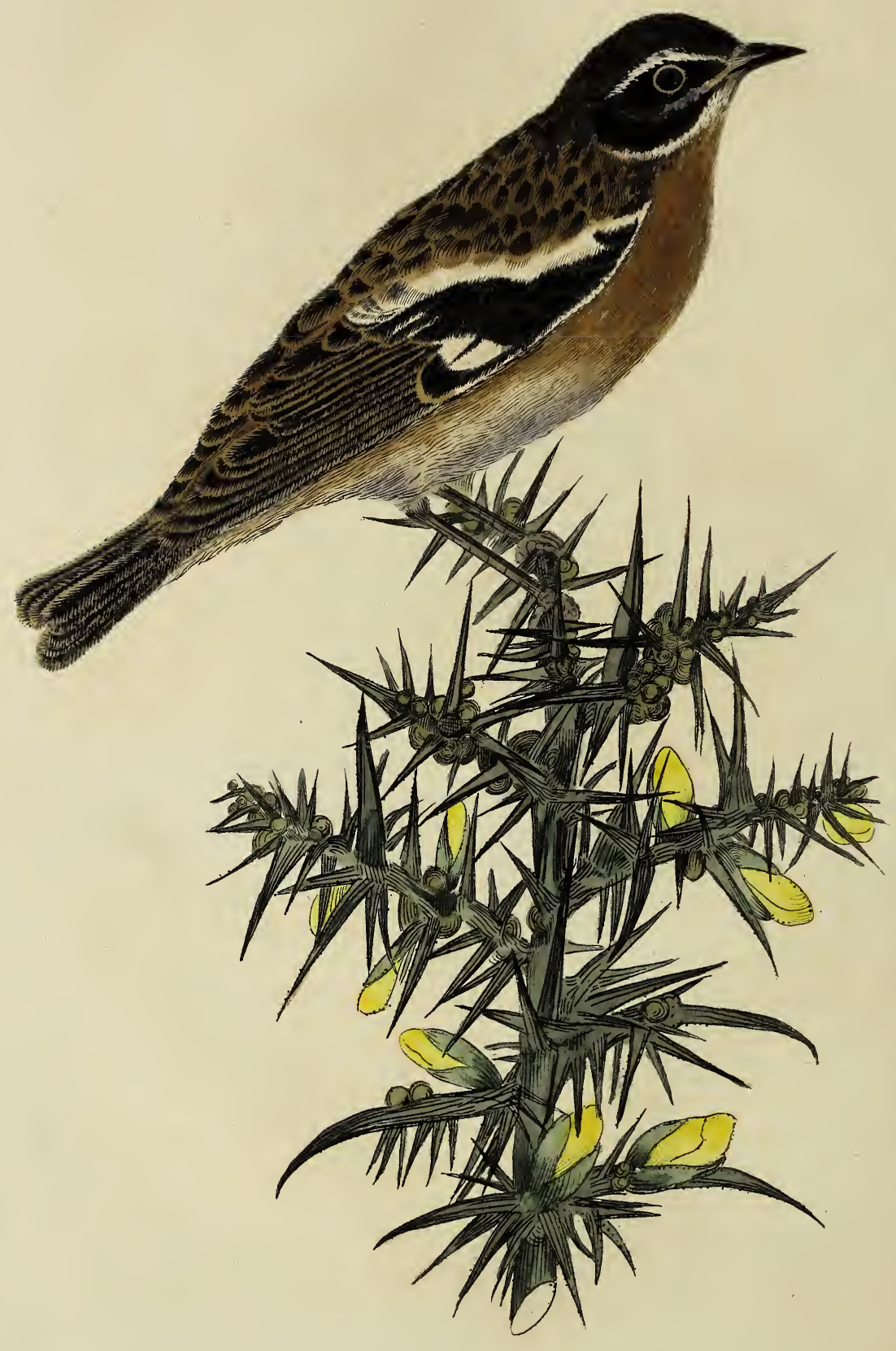




\section{1 \\ SYLVIA Rubetra. \\ The Whin-chat, or Furze-chat.}

S. Rubetra. Dull rufous spotted with black, throat and breast ferruginous, over the eyes and from the chin down the sides of the neck a light stripe, wings with two white bars.

Sylvia Rubetra. Turton British Fauna, v. 1. p. 46.

Head flat. Bill black. Iris hazel. Cheeks black. Wings with two white bars, the upper one longest; and between the white bars is a bright black patch. Quills dusky, with rufous margins. Tail short, blackish, edged with white ; generally moving up and down. Breast and Belly ferruginous, tinged with black. Legs black.

ThIs species, when wild, generally frequents commons, or places where furze-bushes grow, being very fond of perching on them; its head is flat, and the light stroke over the eyes gives it a slight resemblance to a Frog, from which the specific name is derived. Its song is not one of the best; still, among other birds, it makes a pleasing variety ; it is very easily taken in a trap, baited with some living insect, and soon gets familiar in a cage, where it will readily take to feed on the bruised hemp-seed and bread, if a few insects are stuck in it at first; it is also very fond of raw lean meat, cut in small pieces, or of the yolk of a boiled egg; it will feed 
on almost every kind of insect, and is particularly fond of small beetles, ear-wigs, and butterflies.

The bird I at present possess, was caught in July, 1821 ; it began singing about the middle of September, and continued all through the Winter, singing the greater part of the day ; in Spring it sung very loud, beginning in the morning before daylight. I find it one of the tenderest species that I have yet kept; and I have no doubt but the least frost getting at it would cause its death; as in cold weather it appears very melancholy, especially of a morning before a fire is made in the room; but as soon as the room begins to get warm, it enlivens, particularly if a few insects be given it; and I believe it would subsist but a short time, if some were not given it frequently.

Last Summer, I procured a nest of young Redstarts, which were placed in the aviary with the other birds; as soon as they chirped for food, the Whin-chat began to be agitated, and examined them minutely; after a time, it took to feed them, and continued to do so till they were grown up. 


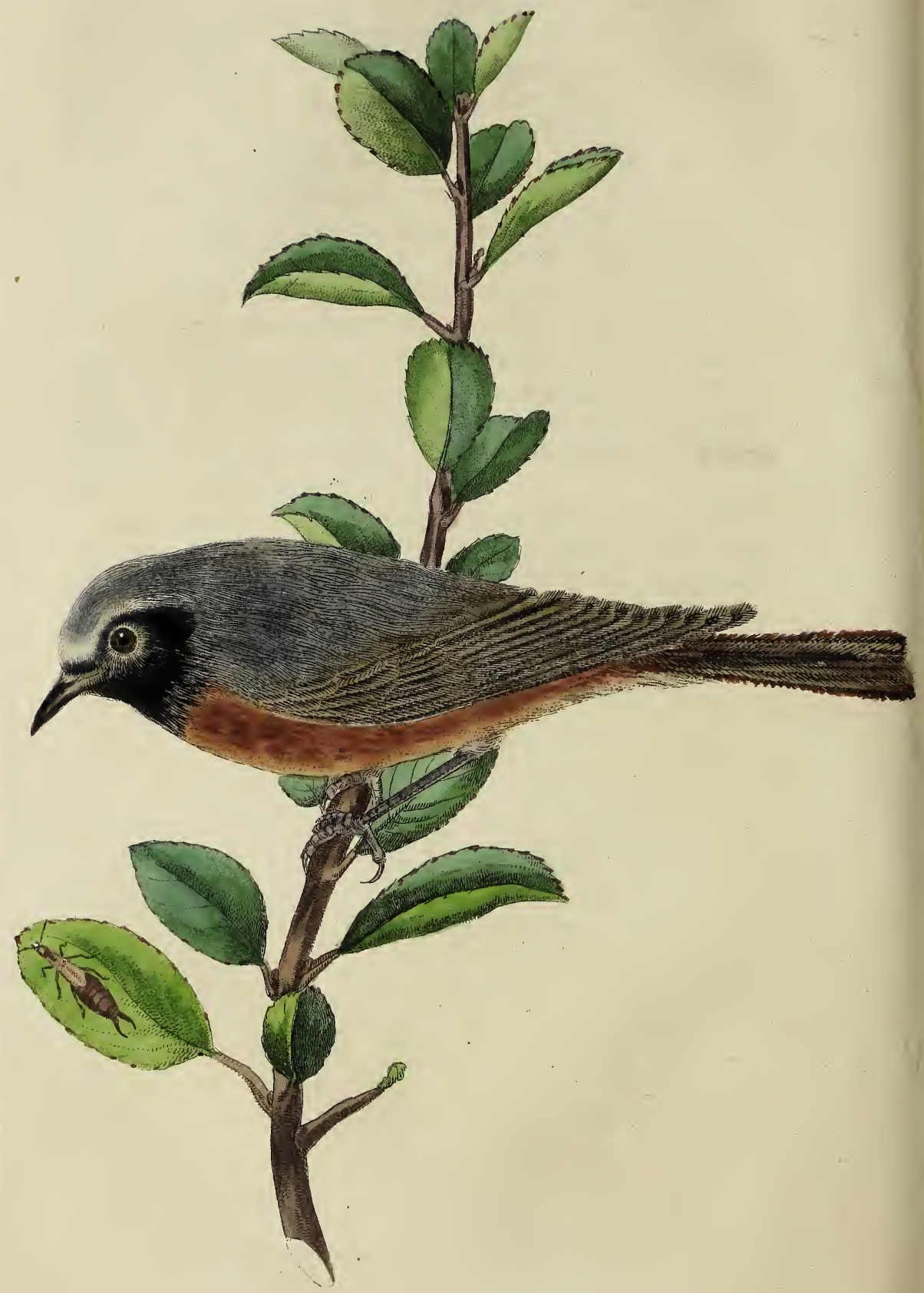

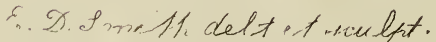




\title{
SYLVIA Phonicurus.
}

\author{
The Redstart.
}

S. Phonicurus. Front of the head white, chin and throat black, head and back bluish grey tinged with brown, breast, rump, and tail rufous.

Sylvia Phœnicurus. Turt. Brit. Faun. v.1. p. 45.

Bill black underneath, lighter at the base, above bluntly keeled. Iris dark hazel. Cheeks and throat black. Sides and belly of a rufous orange colour, whitish towards the tail. Quills brown with lighter margins. Tail rufous, except the two middle feathers, which are dark brown with rufous margins; often moving up and down with a quick motion. Legs black in front, and pale behind. Female, chin whitish, back light brown, and the rufous colour less bright.

Length five inches and a half; extent nine; weight about four drachms.

THIS is a very elegant and interesting species, and a good songster; its food is precisely the same as the last species; in confinement it will sing by night as well as by day, if a light be kept in the room where it is; it will. soon get very tame and familiar in confinement, and will be much attached to the person that feeds it; if brought up from the nest, it may be learned to sing any tune that is whistled or sung to it. One that $I$ was in possession 
of some years back, learnt to sing the Copenhagen Waltz, that it had frequently heard sung, only it would sometimes stop in the middle of it, and say chipput, a name by which it was generally called, and which it would always repeat every time I entered the room where it was, either by night or day. In Winter it would generally begin singing in the evening, as soon as the candle was lighted, and would often sing as late as eleven o'clock at night. When it was hung out by the door in the cage, which it frequently was, the Sparrows would often come round it, of which it seemed particularly fond; it learned their note, and would chirp and call them so exact, that any person who did not know to the contrary, would have supposed it to be the Sparrows chirping.

The Redstart, in a wild state, chiefly visits gardens, lanes, or old buildings, and feeds on various kinds of insects, but seems to prefer the Ants and their eggs. In Spring, when it first arrives in this country, it mounts to the top of the loftiest trees, where it will sit and sing for hours, beginning in the morning by day-break. The earliest time of their arrival that I ever noticed, was the 25th of March ; some years they come the beginning of April, and sometimes not till the middle of that month. It seems to be a very peevish, and fretful bird, often shaking its tail, and repeating a quick shrill note, as if it was in fear; and one that $I$ once reared from the nest, was often allowed to come out of its cage into the room; one day, when wanted to be got in, and not being willing to go, it was drove round the room a few times, which vexed it so much that it would take no food afterwards, though restored to its liberty; it staid sulky for three days, and then died. 



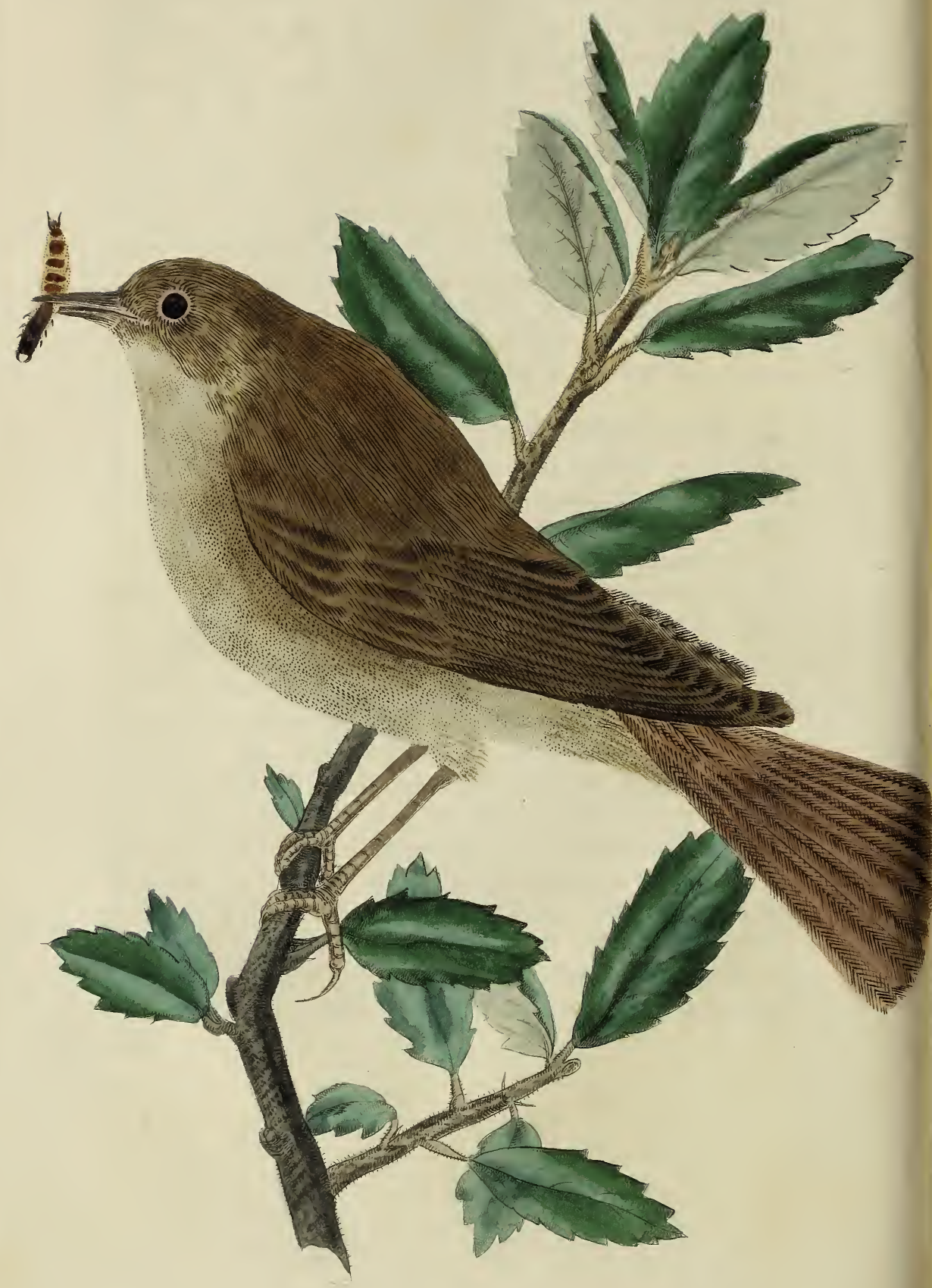




\title{
3
}

\section{SYLVIA Luscinia.}

\author{
The Nightingale.
}

S. Luscinic. Above reddish brown, beneath pale yellowish ash, tail deep tawny red, Sylvia Luscinia. Turt. Brit. Faun. v. 1. p. 44.

Bill dusky, the lower mandible of a white horn colour. Eyes large. Iris hazel. Quills and coverts more or less of a reddish brown, with paler margins. Belly yellowish ash, whiter towards the tail. Upper part of the head and $b a c k$, in some, reddish brown or chesnut, in others, grey brown, (scarcely two are alike in colour.) Tail, generally moving up and down, of a tawny red, composed of several broad feathers, which makes it appear very broad when expanded. Legs very long, light brown.

Length six inches; extent ten; weight from six to eight drachms.

THIs is a very interesting species, and deservedly esteemed for its song, which surpasses that of all other birds, from its variety of notes; it also sings the greater part of the night, as well as by day. In its wild state, it frequents woods, copses, and gardens, where it is often heard, but seldom seen. It generally visits us about London the beginning of April; in Somersetshire it seldom arrives till the middle or latter end of that month, sometimes not till the beginning of May; some counties it does not visit at all. Its food consists entirely of insects of

c 2 
various sorts, but it prefers the eggs of Ants to any other; it is also very fond of the young larvæ of Wasps or Hornets, as I believe are all the species of this genus; but these they can only get when procured for them. In confinement, they will soon take to feed on bruised hemp-seed and bread mixed together, if a few insects be stuck on it; they are also fond of fresh raw meat, but prefer the lean part; the yolk of an egg, boiled hard, and cut up in small pieces, may also be given them in Winter, for a change, if insects cannot be procured; also a little boiled milk and bread; but the more insects they have given them, the better will be their health, and the more they will sing. The larvæ of the Cockchaffer or May-bug, which is sometimes very plentiful in grass fields, may be procured in great abundance, and kept in pots of turfy earth through the Winter, giving each bird one or two of a day, according as the stock holds out. This will keep them in excellent health. Common Maggots also, in the larva or pupa state, they are very fond of, also Spiders, Ear-wigs, Crickets, and various other insects.

The Nightingale is easily taken in a trap. As it generally seeks its food in fresh ground, it is only to clear away a place, and stir up the ground a little, near where it sings or frequents, then set the trap near it, baited with a living insect, and it is almost certain to be caught. Birds caught early in Spring, if put in an aviary with other tame ones, will sing in a few days; those caught the latter part of Summer will begin singing in November, if young ones; but the old ones will seldom begin till $\mathrm{Fe}$ bruary. One that I caught in August, began singing in November, and left off again about the middle of December; at the end of the same inonth it began again, and sung continually all day long against a White-throat, that strived with all its might to outdo it. 



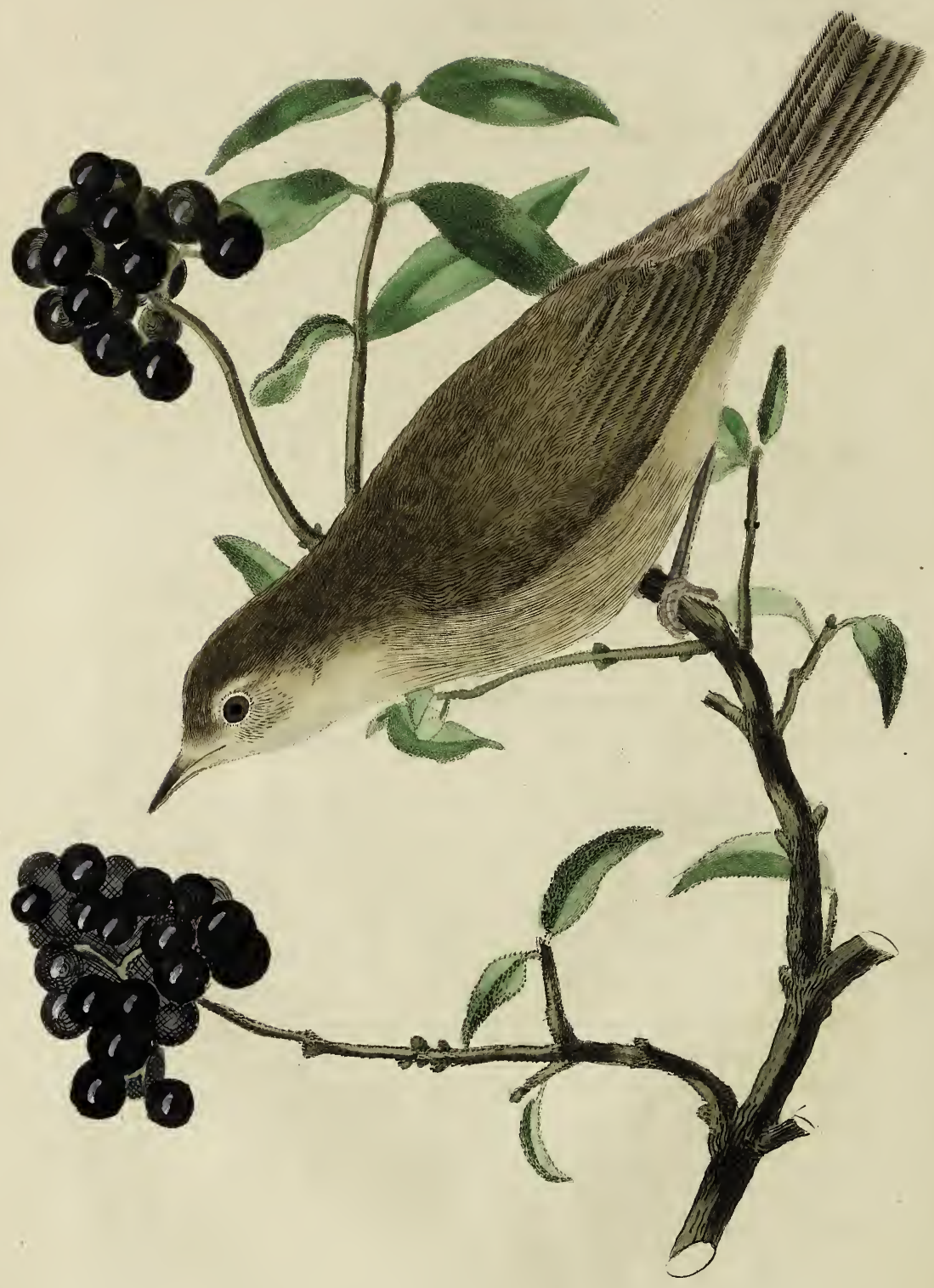




\section{4}

\section{SYLVIA hortensis.}

\section{The Greater Pettichaps, or Garden Warbler.}

S. hortensis. Above light olive-brown, beneath dirty white, from the bill over the eyes a whitish streak, tail-feathers brown; with a grey-brown outer margin, the outmost obliquely half white.

Sylvia hortensis. Turt. Brit. Faun. v. 1. p. 44.

Bill dusky, the base of the lower mandible yellowish. Iris hazel. Upper part of the head and back, of a light olivebrown; in some tinged with a greenish yellow. Quills dark brown, with paler margins. Legs lead colour.

Length five inches and a half; extent nine; weight five to eight drachms.

ThE present species, whose colours are not so gay as some of the others, is nevertheless a plump handsome shaped bird, and its song is scarcely to be surpassed by any of the genus, the Nightingale excepted. It first visits us in the Spring, about the latter end of April, or the beginning of May; and its arrival is soon made known by its very loud and long song. It generally begins very low, not unlike the song of the Swallow, but raises it by degrees, until it resembles the song of the Blackbird, singing nearly all through the day, and the greater part of the time that it stays with us, which is but short, as it leaves us again in August. In confinement, it will sing nearly all through the year, if it be treated well. In a wild state, it is generally found in gardens and 
plantations, where it feeds chiefly on fruit, and will not refuse some kinds of insects; it is very fond of the larva or caterpillar that is often found in great abundance on Cabbage-plants, the produce of $\boldsymbol{P a}$ pilio Brassice, and I know no other bird of the genus that will feed on it. Soon after its arrival here, the Strawberries are ripe, and it is not long before it finds them out; the Cherries it will begin before they are quite ripe; and I know not any kind of fruit or berry which is wholesome, that it will refuse; it generally tastes the Plums, Pears, and early Apples, before it leaves us; and when in confinement, it also feeds freely on Elder, Privet, and Ivy Berries; it is also partial to Berberries, and a soft Apple or Pear.

These birds are not so easily caught as some of the other species; they are more shy of getting into a trap; but in gardens where they are plentiful, they may be taken occasionally in a Nightingale trap, baited with a ripe Cherry or Raspberry, or a living Butterfly or Caterpillar pinned on. They will readily take to feed on the bruised hemp-seed and bread, or on bread and milk; they are also fond of fresh raw meat, both fat and lean; also the yolk of an egg occasionally. To bring them to eat it directly, a few Currants or Raspberries, or other small fruit, must be stuck in it; in eating these out, they taste the other food, which they prefer to the fruit at first, for a change. Fruit of some kind or other, should, if possible, be always kept in their cage. In Winter they are very fond of a roasted Apple; and as soon as the Berries of the Ivy are ripe, they should be supplied with some; they will then succeed very well. 



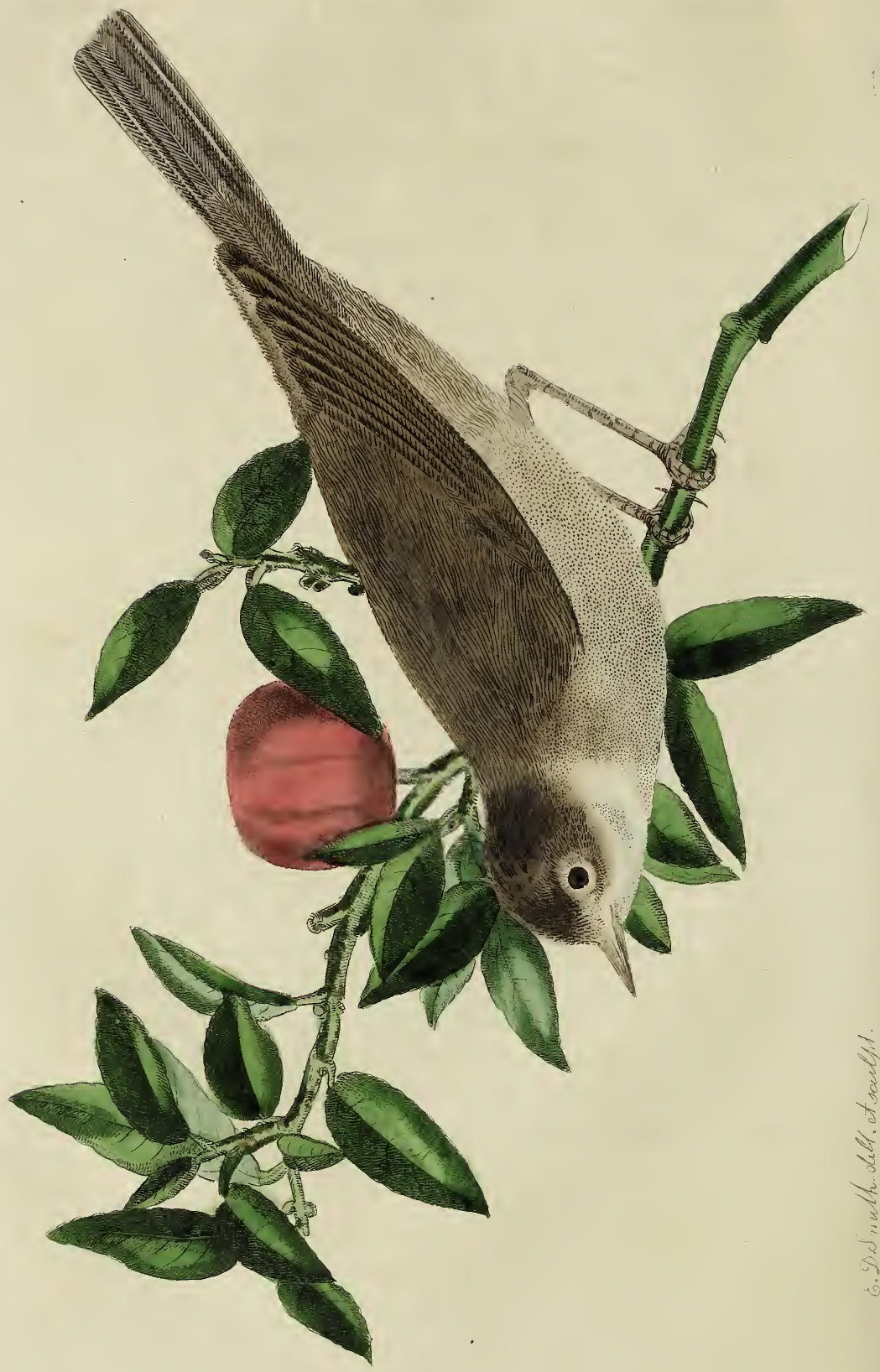




\section{S Y L V I A cinerea.}

\section{The Larger White-Throat.}

S. cinerea. Above brown-grey with a rufous shade, beneath white with a reddish tinge, outmost tail-feathers entirely white on the outer web and half-way down on the inner.

Sylvia cinerea. var. Turt. Brit. Faun. v. 1. p. 45.

Bill dusky, whitish beneath. Iris hazel. Wing-coverts dark-brown, with a dull rufous margin : quills dusky, edged with grey-brown. Throat white: breast and belly, in some, white, in others, slightly tinged with rose. Tail long, dusky, edged with white. Legs pale brown.

Length about five inches and a half; extent near nine; weight about four drachms.

A very lively and interesting species, and one of the easiest preserved; its song also, in my opinion, cannot be surpassed by any bird whatever; it is both lively, sweet, and loud, and consists of a great variety of notes. One that I at present possess will sing for hours together against a Nightingale, now in the beginning of January, and it will not suffer itself to be outdone; when the Nightingale raises its voice, it also does the same, and tries its utmost to get above it; sometimes in the midst of its song it will run up to the Nightingale, and stretch out its neck as if in defiance, and whistle as loud as 
it can, staring it in the face; if the Nightingale attempts to peck it, away it is in an instant, flying round the aviary, and singing all the time.

In a wild state, the present species generally visits hedges and gardens; it arrives in this country about the middle of April, and is often heard singing in a thicket, or in the middle of a hedge; sometimes it mounts up in the air a little way, or flies from one hedge to another, singing all the time. It is readily taken in a trap, baited with a living Caterpillar or Butterfly. One that I caught last Spring, sung the third day after being in confinement, and continued to sing all through the Summer; but this was most likely in consequence of a tame one being with it, which also sung at the same time.

In their native state, these birds feed chiefly on small insects, and a few sorts of fruit, Strawberries and Raspberries in particular; they are very partial to the different species of Aphis, with which almost every tree is covered some time or other in the Summer; they are also very fond of the smaller species of Butterflies, and the common house-fly (Musca domestica); they soon take to feed on the bruised hemp-seed and bread, and also on milk and bread; I have known them to feed on it the day they were caught. Fresh meat, both fat and lean, they also like very well for a change, and the yolk of a boiled egg; also a roasted Apple in Winter. They peck up a great quantity of small gravel, of which there should be always a constant supply in their cage or aviary; if they are without this, they soon get unwell. Fresh water should also be given them every day, in a saucer or pan, large enough for them to get into, as oftentimes they wash themselves two or three times a day. 



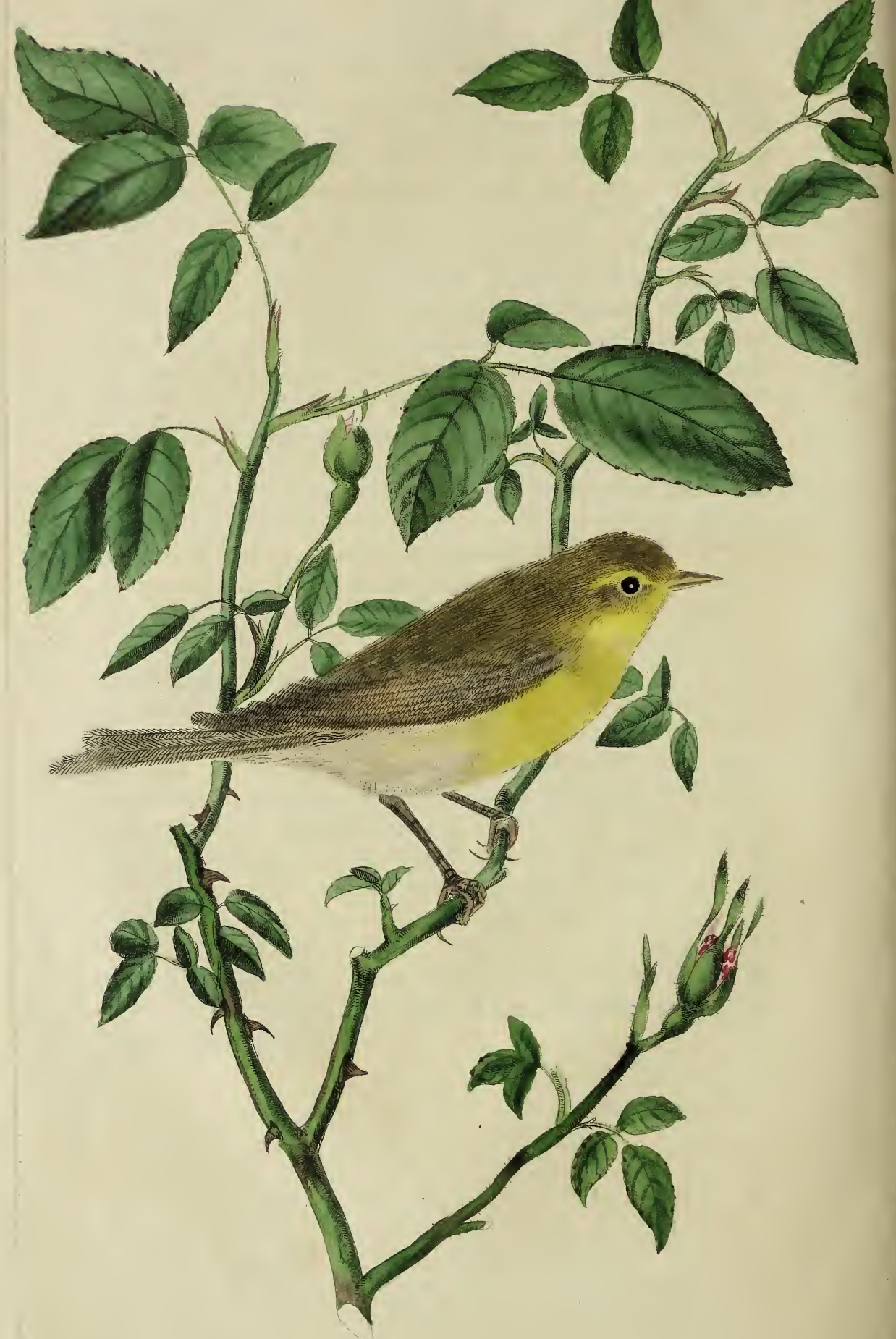

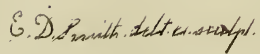




\section{SYLVIA Trochilus.}

The Yellow Willow Wren.

S. Trochilus. Above greenish yellow-brown, beneath pale yellow, over the eyes a yellowish stripe, wing-coverts greenish yellow.

Sylvia Trochilus. Turt. Brit. Faun.v. 1. p. 47.

Bill dusky and keeled above, yellowish beneath. Iris hazel. Breast and throat pale yellow, whitish near the tail. Upper part of the head and back greenish-brown. Quills and tail-feathers dusky, edged with greenish-yellow. Legs brown in front, paler behind; toes yellowish. Female more inclined to brown, and the yellow colour less bright.

Length five inches; extent seven and a half; weight near three drachms.

AN elegant little species, which visits us about the middle of April, and leaves us again the latter end of September, or beginning of October. In its wild state, it feeds entirely on small insects, and, chiefly, on the different species of Aphis ; but it will not refuse small flies, or caterpillars; it is easily taken in a trap, baited with small caterpillars, or a rose branch covered with Aphides; and it will soon become very tame in confinement. One that I caught in September, was, in three days afterwards, let out of its aviary into the room to catch the flies, which were numerous at that season; after amusing itself for some time in catching flies, it began singing; it did the same several other times when it 
was let out, and, in a few days, it began to sing in its aviary. It soon became so familiar, that it would take flies out of the hand; and when it was out in the room, if a fly was held towards it, it would fly up, and take it out of the hand. It was also learnt to drink milk out of a tea-spoon, by putting some flies in it; as soon as it had tasted the milk, it was very fond of it, as most of the birds of this genus are; if the spoon was held towards it, and it was called Sylvia, it would fly up and perch on the finger, or on the handle of the spoon, and drink the milk; but it never got so tame as the next species, neither was it so expert in catching flies; perhaps the reason was, it became so very fat in eating so much bruised hemp-seed and bread, and milk and bread, that it cared but little for any other thing.

These birds are very plentiful some seasons, flying about from tree to tree, and singing their pretty soft note, which is not unlike the song of the Red-breast, but not so loud. Wherever any plants are infested with any kind of Aphis, there the Willow Wrens are almost certain to be, often quarrelling, and flying after one another; and they will even attack other birds that are much larger than themselves.

The Willow Wren seems to be more tender than the next species, to which it is nearly related; when in confinement, it is fond of creeping up to the other birds, for the sake of their warmth, particularly at night; and it will not rest till it is very near to one, against which it squeezes itself as close as possible; this is also the case with $\mathbf{S}$. hortensis. 



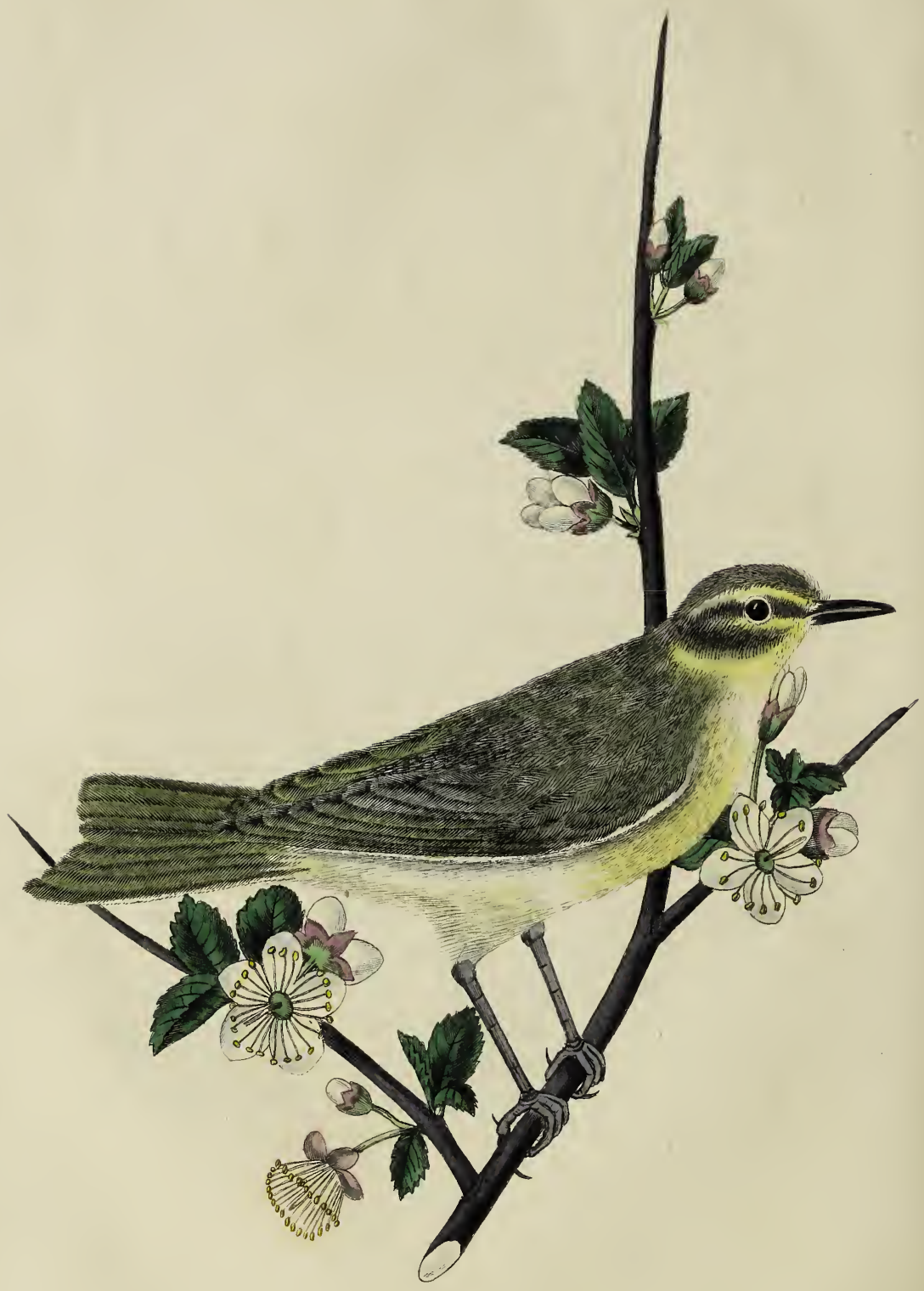




\title{
7 \\ SYLVIA Hippolais.
}

\author{
The Lesser Pettichaps.
}

S. Hippolais. Above greenish-brown, throat and breast dirty yellowish-white, breast and belly silvery-white, above and below the eyes a yellowish streak, quill and tail feathers dusky, with a dirty yellow margin. Turt. Brit. Faun. v. 1. $p .44$.

Bill dusky. Iris hazel. Chin whitish. Lower wing-coverts yellowish. Legs dusky.

Length five inches; extent nearly six inches ; weight near three drachms. Turt. loc. cit.

THIs interesting little species is generally the first of the warblers that visits us in Spring, except S. Enanthe, which occasionally precedes it. The earliest time of their arrival that ever I noticed, was the 12th of March; some years, they do not visit us till towards the end of that month. I have frequently known several days of hard frost after their arrival; so that it is not a very tender bird. On their first coming to this country, they are mostly seen on the forwardest trees in orchards or copses, flying from branch to branch, and from tree to tree, singing their curious song of Chiff-chaff, Chivvychavvy; if the weather is fine and mild, they are continually in motion, flying after each other, and catching the gnats, and small flies, that happen to come in their way. This species, like the last, is very partial to the different sorts of Aphis, which infest the trees and plants in Summer. They are also fond of small caterpillars, flies, and moths; on their first arrival, they feed chiefly on the larva of the different species of Tortrix that are rolled up in the unfolding

D 2 
buds of various trees; the birds of this genus render us much service in devouring those insects, that would, otherwise, destroy a great part of the fruit.

The Lesser Pettichaps is readily taken in a trap, in the same manner as the last species, with which they are often in company in the Summer. They soon get familiar in confinement ; when first caught, they should, if possible, be put with other birds; and they will readily take to feed on bruised hemp-seed and bread, and on bread and milk, which must, at first, be stuck full of small insects, or a quantity of Aphides may be shook off a branch upon it; when they have once tasted it, they will be very fond of it. One that I caught, took to eat it directly, and became so familiar, that, in three or four days, it would take a fly out of the hand; it also learnt to drink milk out of a tea-spoon, of which it was so fond, that it would fly after it all round the room, and perch on the hand that held it, without showing the least symptoms of fear; it would also fly up to the ceiling, and bring down a fly in its mouth every time; at last, it got so very tame, that it would sit on my knee by the fire, and sleep; and when the windows were open, it would never attempt, nor seemed to have the least inclination to fly out; so that I at last ventured to entice it out in the garden, to see whether it would return; I with difficulty enticed it out at the door with a spoon of milk; it returned twice to the room ; the third time, it ventured into a little tree; it then fled and perched on my hand, and drank milk out of the spoon; from thence it flew to the ground on some damp chickweed, in which it washed itself, and got into a hollybush to dry ; after getting among the leaves, I could see no more of it, but heard it call several times. I suppose, after it got quite dry, that it left the country directly, as I could never see or hear it afterwards ; and it was then the end of November, when all the others had left for some time. 



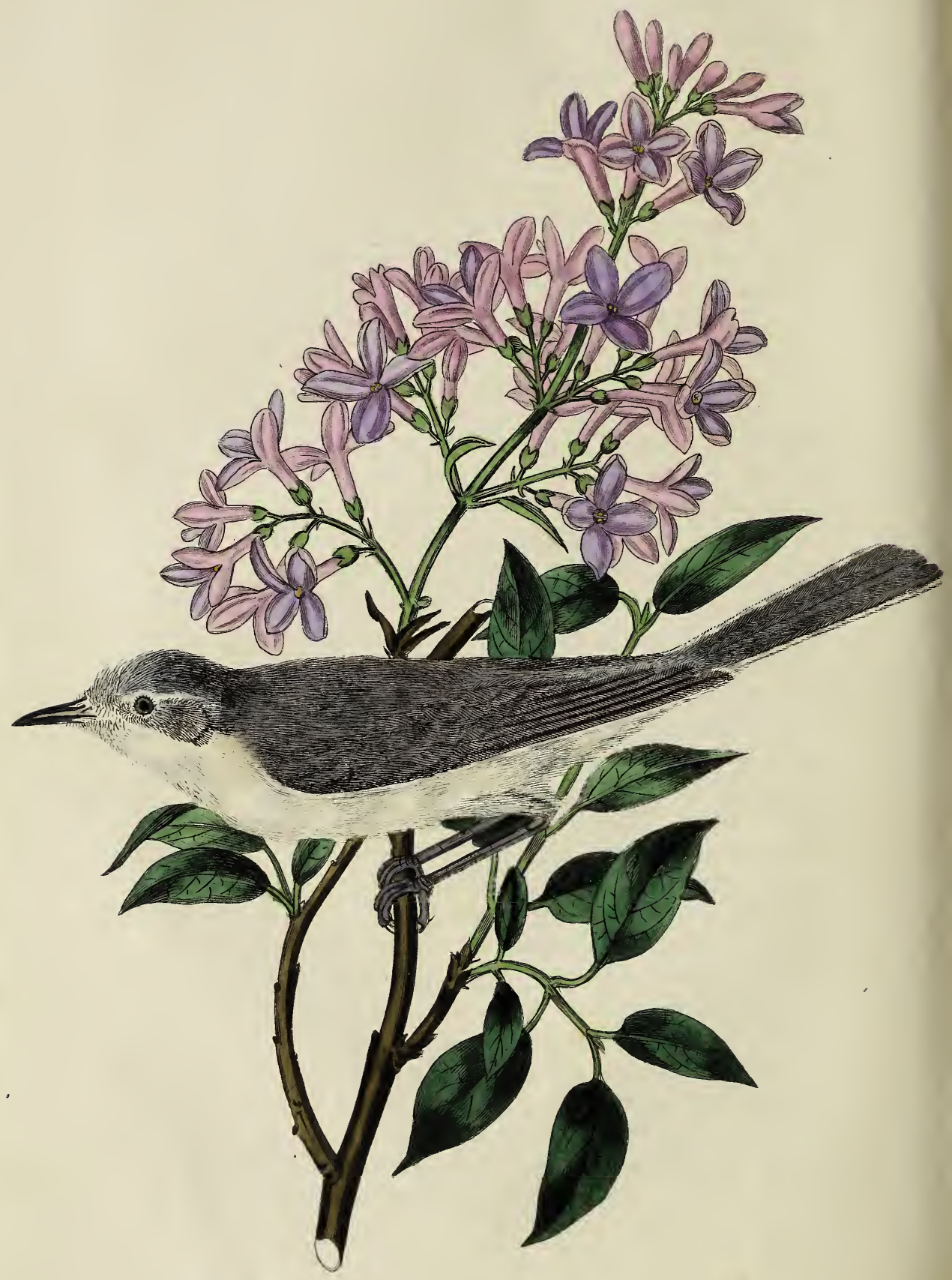




\section{8 \\ SYLVIA Sylviella.}

\section{The Lessser White-Throat.}

S. Sylviella. Head and rump grey, back, wing, and tail grey brown, beneath dirty white, two middle tail-feathers shorter and subulate. Turt. Brit. Faun. v. 1.p. 45.

Bill dusky. Iris yellowish. Quill and tail-feathers darker than the back, with a grey edge; the outer feather of the latter white on the outer web, and more than half on the inner; from the chin to the tail pure white. Legs brown lead-colour.

Length five inches and a quarter; weight three drachms and a quarter. Turt. loc. cit.

ThIs pretty little bird visits us about the middle of April, and leaves us again the end of August, or the beginning of September; its song is not so agreeable as many of the other species ; but, from its singularity, it makes a pleasing variety, being so very different from all the others; in its wild state, it feeds, principally, on flies, and other small insects ; it is also partial to several sorts of fruit, such as cherries, plums, apples, pears, and grapes. In confinement, it will soon become tame and familiar, and will readily take to feed on bread and milk, and also on bruised hemp-seed and bread. One that I bred up from the nest, became so attached to its cage, that it could not be prevailed upon to quit it for any length of time; when the door of it was put open, it 
would generally come out quickly, and first perch on the door, then mount to the top of the cage; from thence it would fly to the top of any other cages that were in the room, and catch any flies that came within its reach; sometimes it would descend to the floor, or perch on a table or chair, and would come and take a fly out of the hand, or drink milk out of a spoon, if invited; of this it was very fond; as soon as it was the least frightened, it would fly immediately to its cage, first on the top, from thence to the door, and would enter in exactly in the same manner as it came out. I have often hung it out at the window, perched on the top of its cage, with the door open, and it would never attempt to fly away; sometimes, if a fly should happen to pass near it, it would fly off and catch it, and return with it to the top of the cage; after remaining there a considerable time, it would either return into it, or fly in at the window, and perch on the cages of the other birds. I sometimes have placed the cage, with its door open, in the garden, where the ants were plentiful; it was always very shy of coming out, and would never venture far from it; and on being the least alarmed, it would return to it again.

I kept this bird through several Winters, and the cold seemed to take no effect on it; at last, a strange cat came into the room where it was, and pulled it out from betwixt the wires of the cage, without leaving a feather behind, it was so very small. 



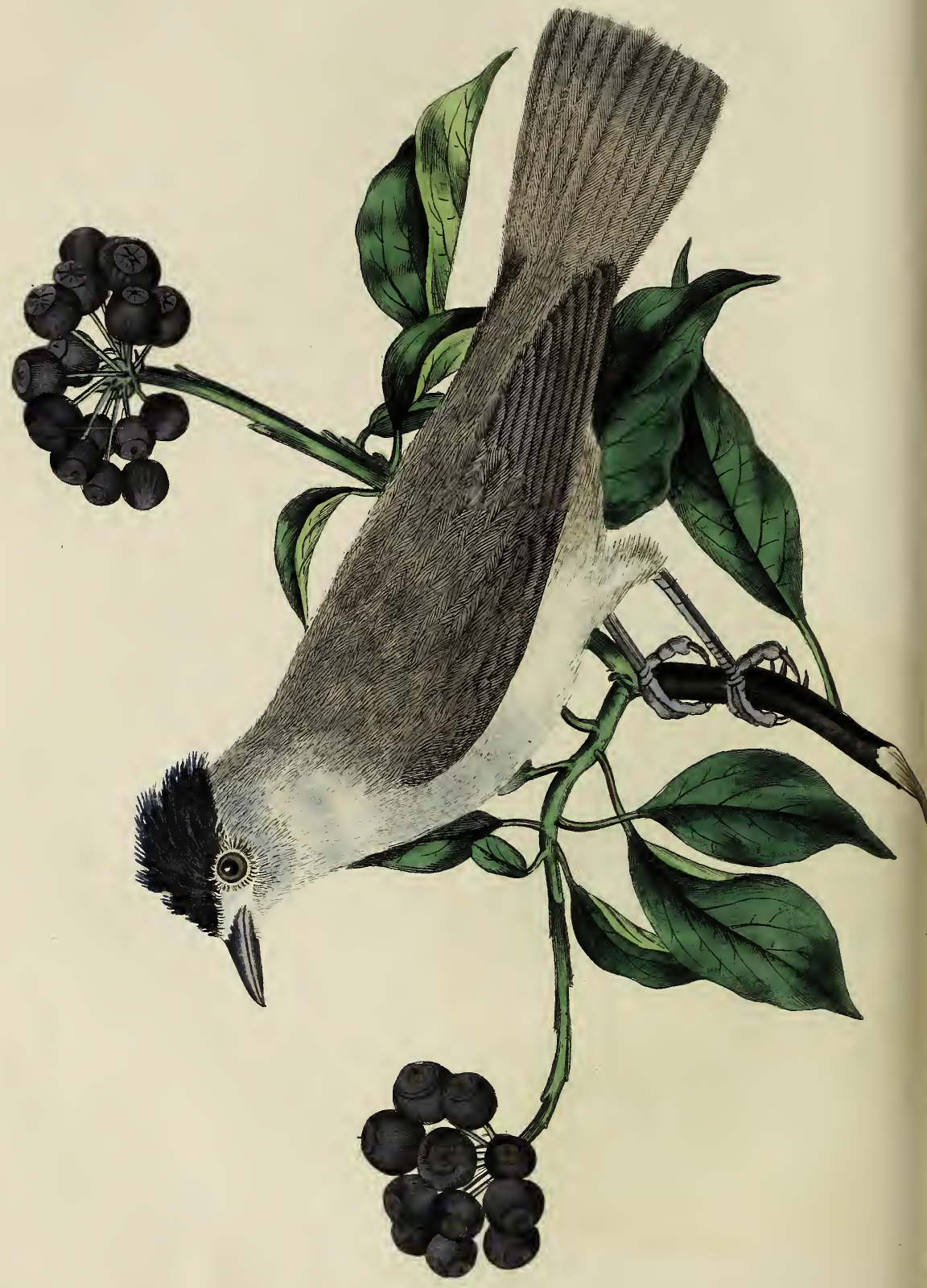




\title{
SYLVIA atricapilla.
}

\author{
The Black-Cap.
}

S. atricapilla. Crown black; of the female chesnut, body above grey greenish brown; of the female inclining to olive, beneath cinereous. Turt. Brit. Faun. v. 1.p. 44.

Bill brown. Iris dark hazel. Cheeks and neck greyish brown. Chin whitish. Quill and tail-feathers dusky, with a greenish brown margin. Belly whitish. Legs lead colour.

Length six inches; extent ten; weight about half an ounce. Turt. loc. cit.

ONE of the finest songsters that visits the British islands, the Nightingale excepted. It generally visits us the end of March, or the beginning of April; the earliest that I ever observed, was the 25th of March; the same day I saw, for the first time that season, a Redstart, a Swallow, and a Srake. I have sometimes known a solitary male bird of this species arrive, and sing every day for a fortnight, before any other was to be seen; I have also seen one as late as the 15th of October.

The song of the Black-Cap is very loud and agreeable, and it has a great variety of notes; it is also a real mock-bird, and will catch the note of any bird that it chances to hear sing; I have heard it imitate the Nightingale so exactly, that it has deceived me; also the Blackbird, Thrush, and the Greater Pettichaps, all of which it imitates so much in its voice, 
that it is almost impossible to detect it, except when it runs from one into the other, or shows itself on the open part of a tree.

In a wild state, this species feeds chiefly on fruit and berries of various sorts; it is also very fond of many sorts of insects, such as caterpillars, butterflies, spiders, \&c. It is not very difficult to take in a trap, baited with a cherry, a living butterfly, or a green caterpillar; it will soon become familiar in confinement, and will readily take to feed on the bruised hemp-seed and bread, if some currants, raspberries, or other small fruit, be stuck in it. To have it always in perfect health, it is requisite that some kind of fruit, or berries, be always kept in its cage ; any sort of fruit, or berry, that is eatable, or wholesome, may be given it; in the Winter, privet-berries, and slices of a mellow apple, or pear, or a roasted apple; also a few flies, or spiders, occasionally.

In confinement, this bird will sing the greater part of the year, and will soon take to sing after being caught; I have known one caught in April, to begin singing the next morning; but it was hung near some other birds. This was the first species of the genus that I attempted to keep through the Winter; and it was several seasons before I could manage it well ; but as soon as I found out that it would feed on the bruised hemp-seed and bread, my difficulty was at an end; and I had no doubt but all the other species would feed on the same sort of food; this proves to be correct, as far as I have had an opportunity of deciding. 



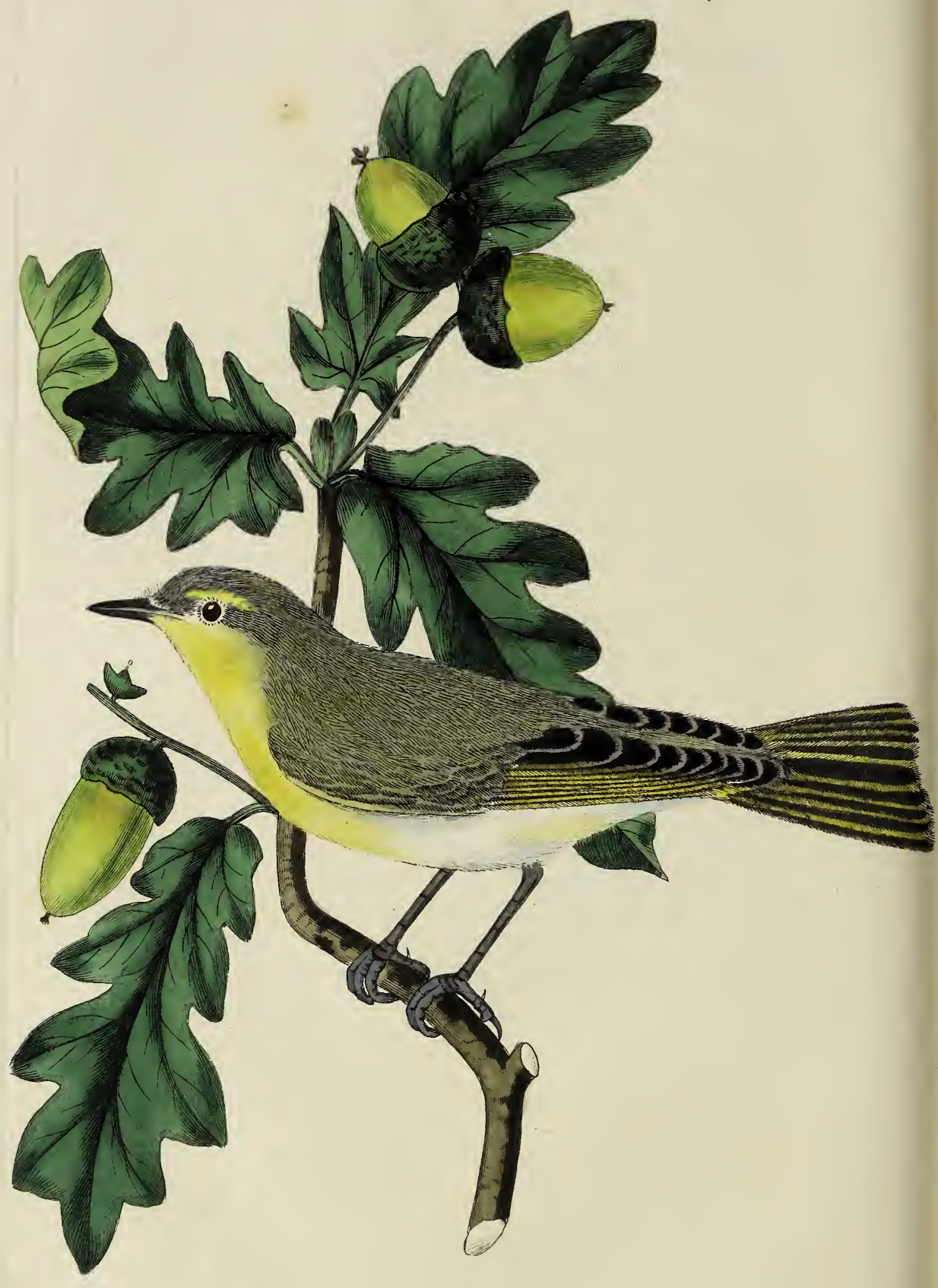




\section{0 \\ SYLVIA sylvicola. \\ The Wood-Wren.}

S. sylvicola. Length five inches and a half; bill horn-colour; upper mandible bent at the tip, and rather longer than the under; irides hazel ; nostrils beset with bristles; top of the head, neck, back, and tail-coverts olive-green; throat and cheeks yellow, paler on the breast; belly and vent of a most beautiful silvery white; through the eye passes a yellow line : wings and coverts brown, edged with green; tail consisting of twelve feathers, rather forked, and of a brown colour, edged with green on the exterior webs, and with white on the interior, the first feather wanting the green edge; under part of the shoulder bright yellow; legs rather more than an inch long, of a horn-colour; claws paler. T. Lamb in Linnean Transactions, v. 2. p. 245. $t$. 24.

Sylvia sylvicola. Montagu Linn. trans. v. 4. p. 35. Turt. brit. faun. v. 1. p. 45.

Sylvia sibilatrix. Beckstein. Temminck Manual D'Ornithologie. v.1.

An elegant and interesting little bird, which arrives in this country the beginning of April, and leaves it in August or the beginning of September. I have never observed it in any other situation than amongst tall trees, in woods or plantations, where it is readily detected on its arrival, by its shrill shaking sort of note, which may be heard at a great distance, and cannot be confounded with the song of any other bird; when it first arrives, it continues to sing nearly all day long, and its song is continued more or less through most part of the Summer, except the time that it is engaged in feeding its young; it is then discovered by a dull mournful sort of call, quite different from that of any other bird; it may be easily watched to its nest, which is built on the ground in a thicket of small bushes, and consists of moss and dry leaves, with a covering at the top of the same materials, so that it is scarcely possible to discover it, without watching the old birds to it, either when they are building, or carrying food to their young. I believe they are to be found in most woods and large plantations in Summer. I have frequently heard them in Kensington Gardens amongst the tall trees; and they are not uncommon in Coombe-wood in Surrey, where I procured a nest with young ones last Summer; and I find they may be reared by hand from the nest very 
readily; when they will be very tame and familiar; and any birds of this tribe may be reared from the nest in the same manner.

The method that I practise in breeding them up, is to let the young birds be nearly fledged; I then place the nest in a little basket with covers, nearly filled with moss, which keeps them warm; and I feed them with moist bread and bruised hemp-sced mixed together, and small bits of raw meat mixed with it; I also give them a little bread and milk, and the yolk of an egg boiled hard, not forgetting to let a drop or two of water fall into their mouths occasionally; they require to be fed several times a day, giving them as much as they will take at each time; they must also be kept clean; for if allowed to get dirty, they will not succeed; as soon as they are fed, the covers of the basket must be shut down, and they will in a few days learn to peck, and feed themselves; but they will peck at living insects before they will learn to eat the other sorts of food: when they are properly fledged, a little fine gravel should be mixed with their food, as this turns to lime, and hardens their bones, and keeps them from being cramped.

The first notice we have of this bird as a native of England, is by Mr. T. Lamb, in the second volume of the Linnean Transactions above quoted, and I have known it as long as I have known any thing about birds, it being plentiful in the woods of R. Bright, Esq. of Hamgreen, near Bristol, where it was known when I was a boy, by the name of the Shaking-bird of the Wood, from its singular note, which sounds as if it was shaking as it utters it, and which it really is, as may be readily seen by any person who will take the trouble to notice it. I have adopted Montagu's name for this species, as I believe it has the right of priority.

In my opinion, the present species is as well worth keeping in a cage or aviary, as any one of the genus, as it is an elegant bird, and has a pleasant and singular song; it feeds readily on the bruised hemp-seed and bread, and a little raw lean meat mixed with it, also bread and milk; but it is most partial to the yolk of an egg, boiled hard and crumbled; it is also very fond of flies, small moths, caterpillars, the different sorts of aphis, and many other insects. 


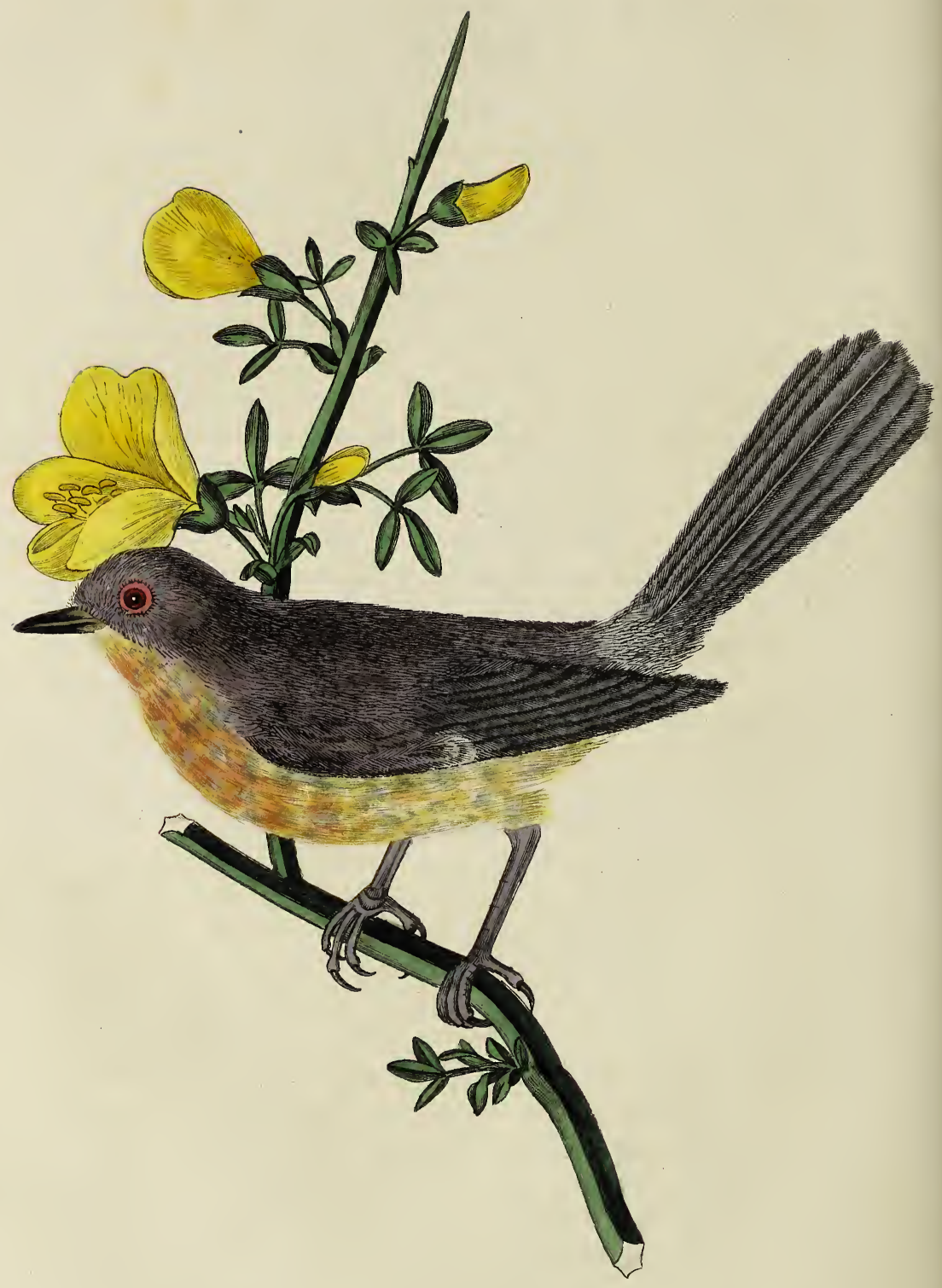


\title{
11
}

\section{SYLVIA provincialis.}

\author{
The Dartford Warbler.
}

S. provincialis. Deep rufous brown, beneath ferruginous, belly white in the middle, iris and eyelids red, legs yellow.

Sylvia provincialis. Temminck. man. d'ornith. v. 1. p.211.

Sylvia dartfordiensis. Montagu in Linn. trans. v.9. p. 191. Turt. brit. faun. v. 1. p. 46.

Bill black, whitisle at the base of the upper mandible. Throat with a few whitish spots. Cheeks dark grey. Quills dusky, edged with dark grey. Spurious wing white. Tail wedge-form, brown, the outmost feathers white on the outer edge. Turt. loc. cit.

ONE of the rarest of the British species of this tribe, but mentioned by Montagu as not uncommon about Kingsbridge, Devon; and in the neighbourhood of Truro, Cornwall ; it is also occasionally met with on Bexley-heath, near Dartford, Kent; also on Blackheath, and on Wandsworth and Wimbledon commons; where it is said to build in the Furze bushes, and feeds on grasshoppers, moths, butterflies, caterpillars, ants, and various other insects. I have never yet been able to procure a living bird of this species, although there is no doubt but it might be readily caught in a Nightingale trap, baited with a caterpillar or some other living insect; or young ones might be easily bred up from the nest, in the same manner as mentioned under the other species.' Should any of my Subscribers be able to 
procure me one of them, or a nest with young ones, I should feel much obliged, and would be willing to purchase it, or exchange any other sort that 1 have to spare, in return.

In confinement these birds should be managed exactly the same as the other species, and will without doubt take to feed readily on the bruised hemp-seed and bread, with some bits of raw meat cut small, and mixed with it: to bring them to eat it immediately when first caught, it will be requisite to stick it full of flies, or caterpillars, or other small insects; some of the yolk of an egg boiled hard, should also be given them occasionally for a change, and as many insects as can be procured, which will be the means of keeping them, and all the birds of this tribe, in excellent health, and will make them sing more, and louder than they would otherwise do. 

:

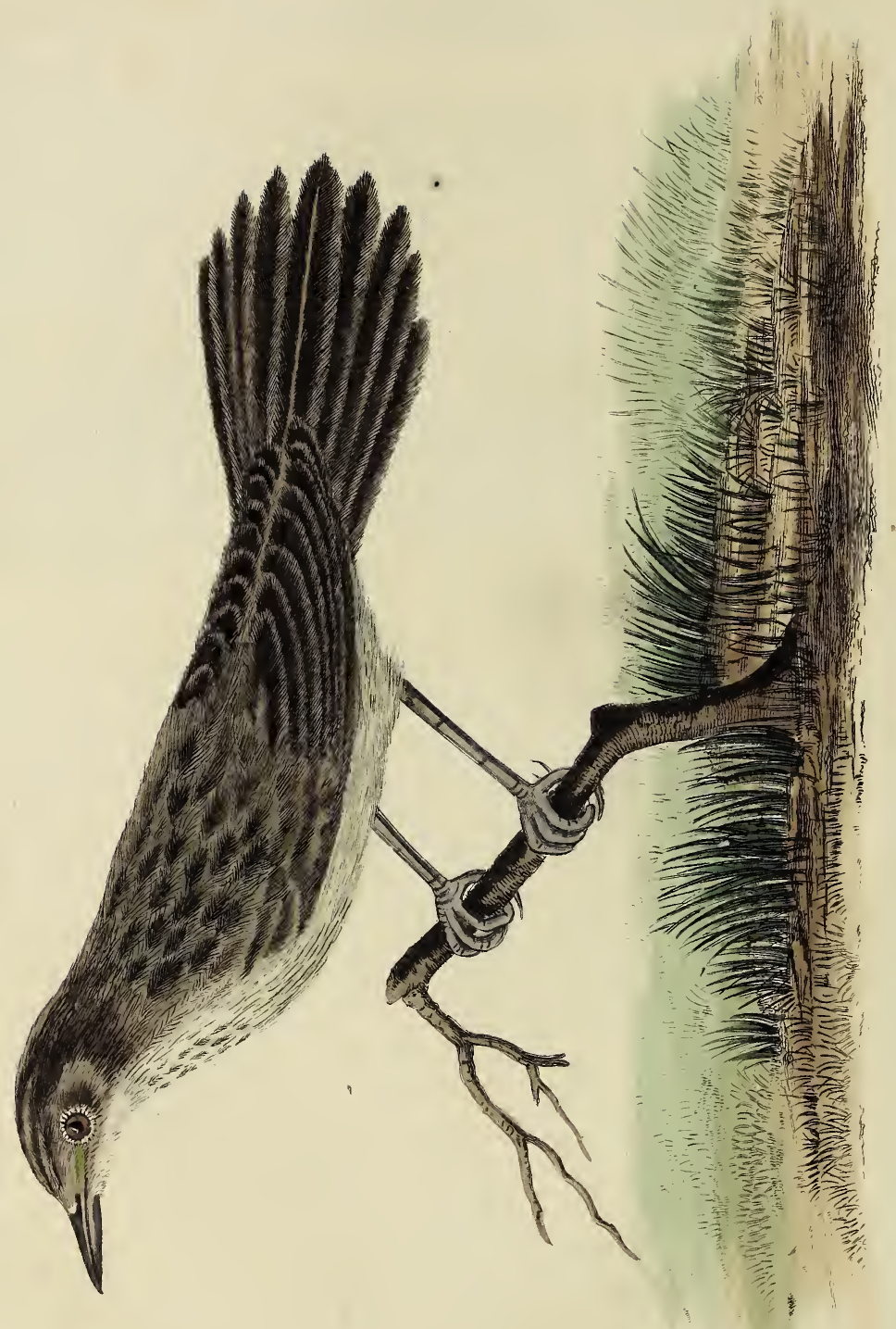




\section{SYLVIA Locustella.}

\section{The Grasshopper Warbler.}

S. Locustella. Olive brown, with dusky spots, beneath yellowishwhite, darker on the breast, tail wedge-shaped with pointed feathers. Turt. Brit. Faun.v. 1. p. 45.

Bill dusky above, pale beneath. Iris hazel. From the bill to the eyes a yellowish streak. Breast and sides inclining to brown, with a few dark streaks. Quills and tail dusky, olive-brown, with paler outer margins. Legs pale brown. Length five inches and a half; weight three drachms and a quarter. Turt. loc. cit.

The present species is very rare in the neighbourhood of London, and I have never seen more than a single living one myself, any where in the vicinity; that one I caught in a Nightingale trap, about the middle of August, 1823, in Mr. Colvill's late Grosvenor Nursery, in the Five Fields, near Grosvenor-place, which is now partly covered with houses: I kept it till the February following; and it would have succeeded well, had I not allowed it to wash so much, not thinking at the time that the washing would hurt it; so that it frequently washed itself three or four times a day, which at last weakened it so much, that on a cold day it caused its death. It never attempted to sing while I had it in confinement, which was probably from its being an old bird ; and I have not been able to procure another since. It thrived remarkably well on the same E 2 
sort of food as the other birds of this tribe, but was particularly fond of the yolk of an egg boiled hard, also of the raw lean meat, that was cut up small, and mixed in the bread and bruised hemp-seed; it would also occasionally feed on the bread and milk, but it was not so fond of that as some of the other birds. Insects of various sorts it was very partial to, particularly small caterpillars, ants eggs, spiders, moths and butterflies, and flies of various sorts; the latter it was very dexterous in catching when they came near its cage.

These birds are not uncommon in several parts of England; they are said to be plentiful on Malmsbury Common, Wiltshire, in Summer, where they breed; they are also frequently seen in Norfolk and Suffolk, and in various other parts, where they build their nest among some high grass or sedge, in which it is so concealed that it is with difficulty found, except by watching the old birds carrying food to their young; or when they are building they may be seen carrying materials to construct their nest. The young ones may be easily reared by placing their nest in a little covered basket, nearly filled with dry moss or soft hay, and to be fed whenever they require it, with the same sort of food, as recommended for the old ones; being careful to keep them clean, and a few very small gravel stones should be mixed with their food occasionally, that their bones may become strong and firm, so that they may not be cramped; should any of my readers be able to procure me a nest, I should feel much obliged, and would willingly give any sort of which I possess duplicates in return. 


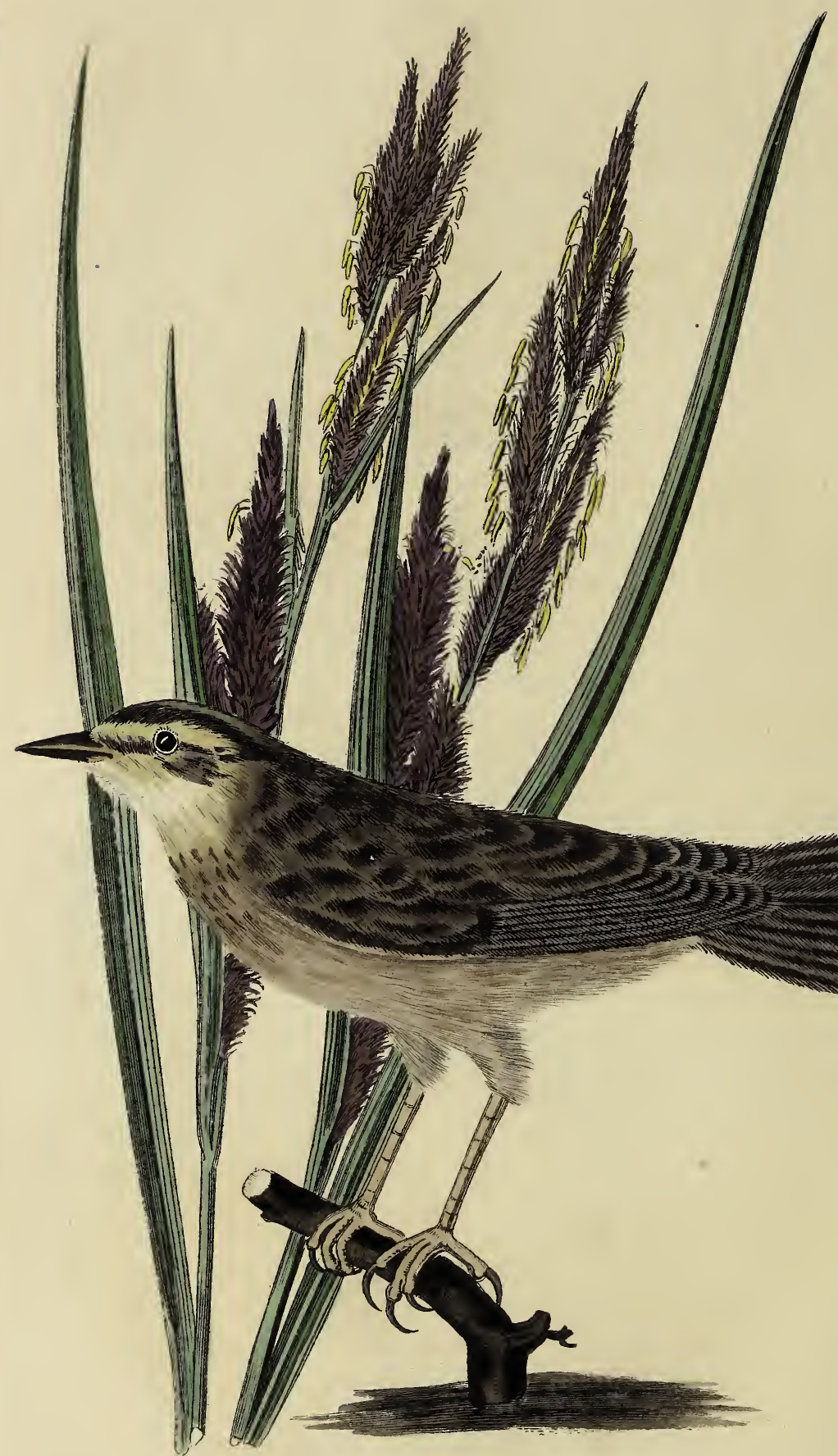


\title{
13 \\ SYLVIA Phragmites.
}

\author{
The Sedge Warbler.
}

S. Phragmites. Yellowish brown, with dusky spots, beneath dirty white, tail-coverts pale tawny, over the eye a white stripe.

Sylvia Phragmites. Temm. man.d'ornith. v. 1. p.190. Linn. trans. vol. 15. p. 17.

Sylvia salicaria. Turt.Brit. Faun. v. 1.p.46. not of Linnaus.

Bill black, pale beneath, broad at the base. Cheeks pale brown; over the eye-brows a black stripe. Breast and sides darker. Quills and tail dusky, the former edged with olive-brown. Tail a little wedge-form. Legs dusky : toes large.

This pretty little species is very plentiful in the neighbourhood of London, which it visits the beginning of April, and leaves again in September, frequenting the sides of the river, or any ditches, where there is a thicket of Reeds, or Sedge, in which it builds its nest, and is almost continually in song, both by day and night ; its song consists of a variety of notes, some of which are very loud, and may be heard at a considerable distance, generally beginning with chit, chit, chiddy, chiddy, chiddy, chit, chit, chit. It is readily caught in a Nightingale-trap, baited with a living green caterpillar or a butterfly, as in a wild state it feeds entirely on living insects; almost all sorts of flies, small moths, and butterflies, besides various sorts of caterpillars, and other small insects. It is a very lively 
bird, and shows scarcely any symptoms of fear, approaching very near to any person who does not drive or frighten it, and it soon becomes very tame and familiar in confinement, where, if well managed, it will sing the greater part of the year.

The present species, when first caught, should, if possible, be placed in a large cage or aviary with some other small birds, and must at first be supplied with some sort of insects ; flies, caterpillars, or maggots, should be put in a little pan, and when the bird has found them out, and begins to feed on them, some of the bruised hemp-seed and bread, with some bits of raw lean meat mixed up with it, should be placed in the same pan, with some insects stuck in it, that in picking up the insects it might taste the other food, and it will soon take to feed on it freely; some of the yolk of an egg, boiled hard, should also be bruised up, and moistened with water, that it might stick to the insects, which are also to be stuck in it; when the bird has tasted this, it will eat it readily, as it is particularly partial to egg after once tasting it; and it does for a change in the Winter instead of insects, when very few of them are to be procured.

Those birds are particularly partial to washing themselves in water, if it be placed in a pan in their cage or aviary; at some seasons they will wash three or four times in a day, this will not hurt them in Summer when the weather is warm, but it weakens them very much if they are allowed to wash in Winter; once a week is often enough at that season, and then the water should be put in the cage in the morning, and after they have washed it should be again removed, they will then have time to dry themselves properly before the evening.

I have no doubt but the present species, with S. arundinacea, and S. Locustella, and some other exotic species, will be hereafter divided from this genus, and also from the other Warblers, and will form a distinct one of themselves. 


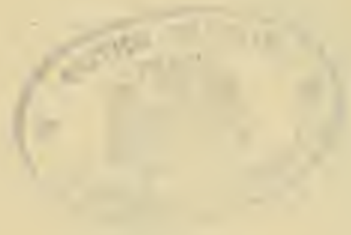




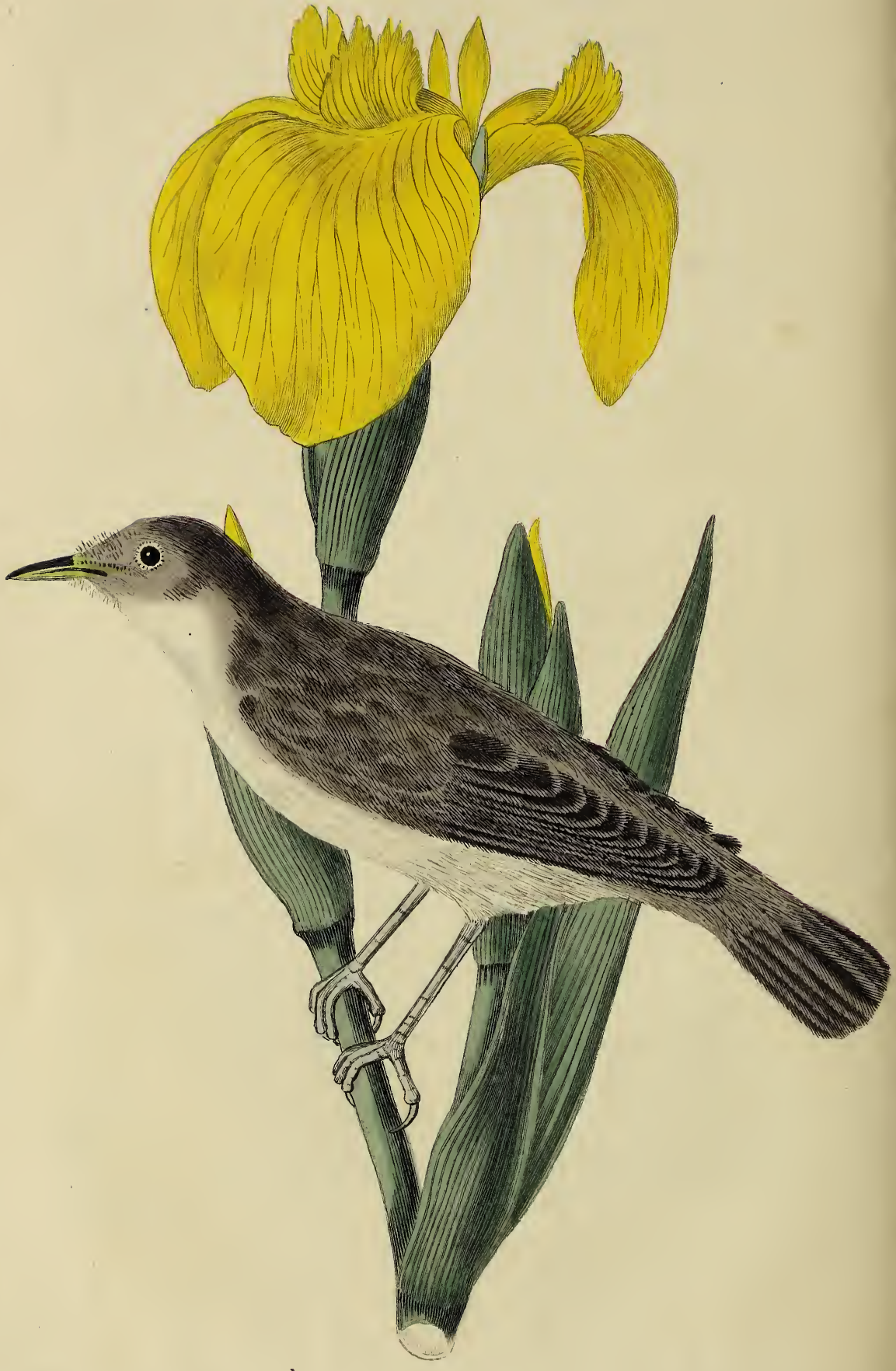




\title{
14
}

\section{SYLVIA arundinacea.}

\author{
The Reed Warbler, or Reed Wren.
}

S. arundinacea. Above olive brown, beneath yellowish white, lores and orbits whitish brown, wings with a tawny yellow band in the middle underneath, tail brown, somewhat wedge-form. Turt. Brit. Faun. v. 1. p. 45.

Bill dusky above, yellowish beneath, broad at the base. Iris hazel. Sides inclining to rufous brown. From the bill to the eye a lightish streak. Quill and tail-feathers dusky, with olivebrown margins. Legs dusky. Soles greenish.yellow.

Length hardly five inches and a half; weight about three drachms.

Turt. loc. cit.

A PRETTy little lively species, generally frequenting the sides of rivers and ditches when in a wild state, where its warbling song may be heard amongst the Reeds, and Sedges, or other thickets, that are near the water; visiting us the beginning or middle of April, and leaving again in September; towards Autumn it sometimes leaves its usual haunts, and frequents the gardens for the sake of insects; it is particularly fond of the common house-fly (Musca domestica), and I have frequently seen several of them in August and the beginning of September by the side of large dung-heaps, where those flies breed, and about that time are coming out from the pupa state in great quantities; they may then be readily taken in a trap baited with a small moth or green caterpillar; when first caught they should if possible be put in a cage with other tame birds, or if one is placed in a cage by itself, it should be set near 
a cage with some other bird in it, which reconciles it to confinement, being so very wild and restless when first caught, that if there is not another bird with, or near it, there will be very little chance of its living; but it soon becomes very tame and familiar in confinement, and in a very short time will be sociable enough to take a fly, or other small insect, from the hand of the person who attends to it.

In confinement the birds of this species will readily take to feed on the bruised hemp-seed and bread, and some raw lean meat mixed with it; to make them take to it immediately, a little should be placed in a small pan or dish, mixed up with a quantity of flies or other small insects, and others stuck on the surface of it; some yolk of a boiled egg should also be done up in the same manner; when once they taste this, they are particularly fond of it; the egg should not be mixed with the bread and hemp-seed, but be given by itself as a change of food ; any small insects, such as the smooth caterpillars, moths, butterflies, spiders, grasshoppers, crickets, ants, and various other insects, they are very partial to, and the more is given them, the better will be their health and spirits; like the Sedge Warbler, the present species is very fond of washing often in a pan of water, which is beneficial to their health in Summer, but is very hurtful in Winter; at that time they should be only allowed sufficient to drink, or only be let wash about once a week; they are very restless when the time arrives for them to be on their passage, which lasts a considerable time.

I once found a nest of these birds, with five young ones; it was fastened up to the side-branches of a Poplar-tree, that grew at a little distance from the river, in Broomhouse-lane, Fulham. 

2

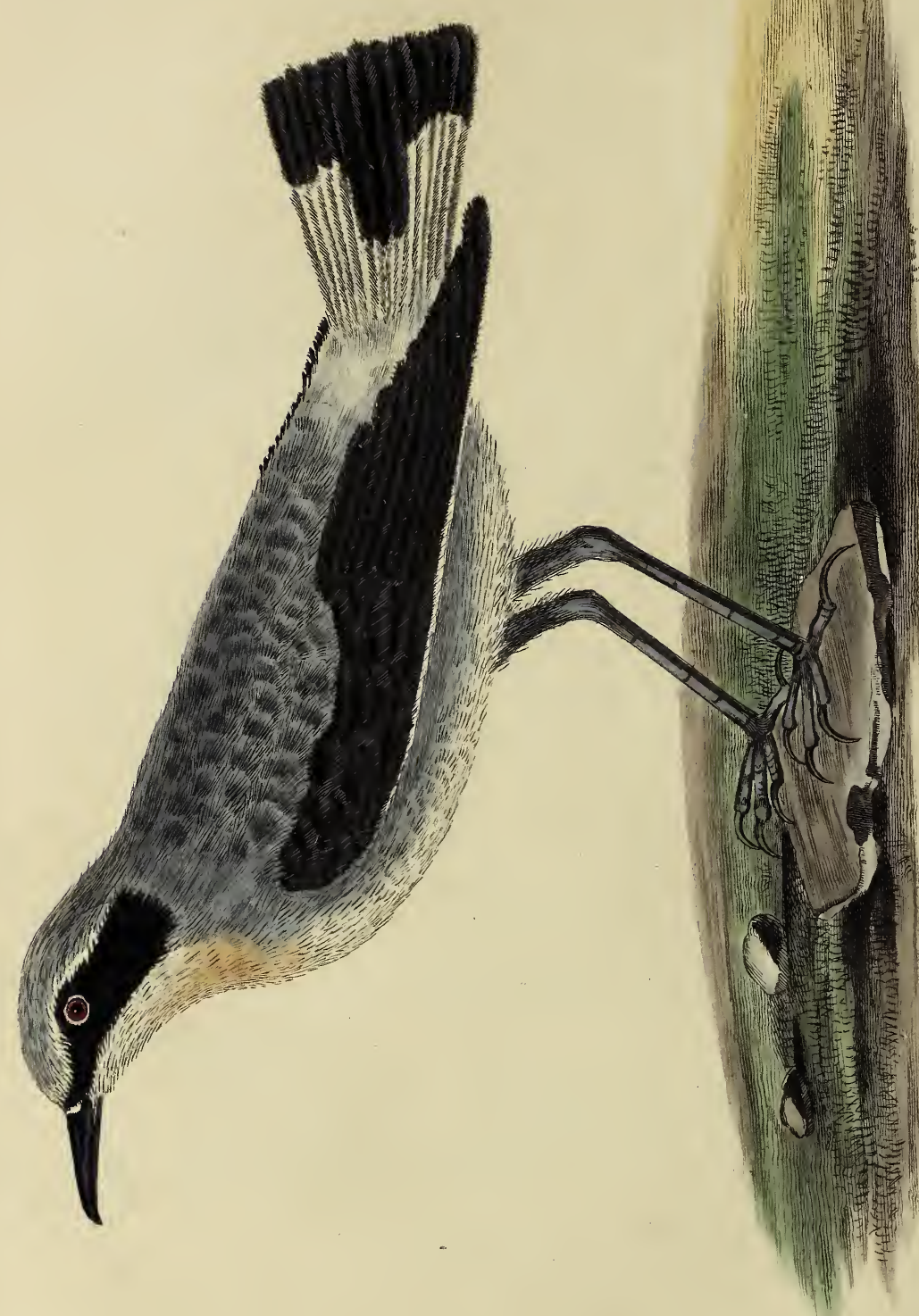

है 


\section{5}

\section{SYLVIA Enanthe.}

\section{T'he Wheat-Ear, or White-Rump.}

S. Enanthe. Head and back bluish grey, cheeks black, over the eyes a dirty white stripe, breast and belly light rust-colour, rump and base of the tail white.

Sylvia OEnanthe. Turt. Brit. Faun. v. 1. p. 46.

Saxicola Enanthe. Beckstein. Temm. man. d'orn. v. 1. Linn. trans. v. 15. p. 20.

Bill black. Iris hazel; from the bill a black stripe, forming a black patch round the eyes. Front dirty white. Wings and coverts dusky, with reddish brown edges. Breast with a reddish tinge, under the tail white. Tail often moving up and down. Two middle tail-feathers white with a black base, the rest white tipt with black. Legs blackish.

Length about six inches; extent near twelve; weight near seven drachms. Turt. loc. cit.

A very lively and interesting species, which arrives in this country in March, and generally leaves it in September or October, though sometimes they stay till the middle of November; I observed a pair on the 17 th of November last, near the gravel-pit in HydePark, which were quite lively, and flying about after the insects, as brisk as if it had been the middle of Summer; from their appearance I should suppose they had been about there for some time, as they were not at all shy, but would allow me to come within three yards of them, so that they might have been easily caught in a trap, if I had wished for them; but being previously in possession of a pair, I did not trouble myself about them.

In a wild state, these birds are chiefly to be found on hills or commons, and very frequently in parks and rabbit-warrens; in some counties they are so plentiful 
that some hundred dozens are caught annually by the Shepherds, who sell them for the sake of their flesh, which is very delicious, particularly in Autumn, when they become very fat: I believe it is not generally known that S. hortensis, or the Greater Pettichaps, also become quite as fat, and its flesh is quite as delicious, or perhaps more so, as it feeds almost entirely on fruit.

1 have seldom heard the Wheat-ear sing when wild, and when I have, its song was very soft, and scarcely to be heard, except when very near it; though I must allow I have never been much in the places that they frequent in Summer, so that they may sing more than I am aware of ; but in confinement, they are almost continually in song, and sing by night as well as day; they have a very pleasant, variable, and agreeable song, different from all other birds, and sometimes it is very loud, and they continue it a great length of time, not continually breaking off like a Robin-Redbreast, and some other birds; but their Winter song is best, and most varied: a pair that I possess at present were caught in September last, and they began to sing in a few days, and have continued in song ever since, and now while writing this, the twenty-second day of December, they are in full song. When in a large cage or aviary where there is plenty of room, it is very amusing to see them at play, flying up and down, and spreading open their large wings in a curious manner, dancing and singing at the same time.

In confinement these birds require the same sort of food as the Stonechat, Whinchat, and Nightingale, feeding freely on the bruised hemp-seed and bread, with some fresh, raw, lean meat, cut up in small pieces and mixed with it; they are also very fond of the yolk of an egg boiled hard, which should be given separately, also almost all sorts of insects, except the common earth-worm; all the sorts that the Nightingale or Whinchat will eat, they are also very fond of, and the more they have given them the better, and the more they will sing: they are particularly fond of cockroaches and crickets, so that any person acquainted with a baker may always procure plenty from his shop. 



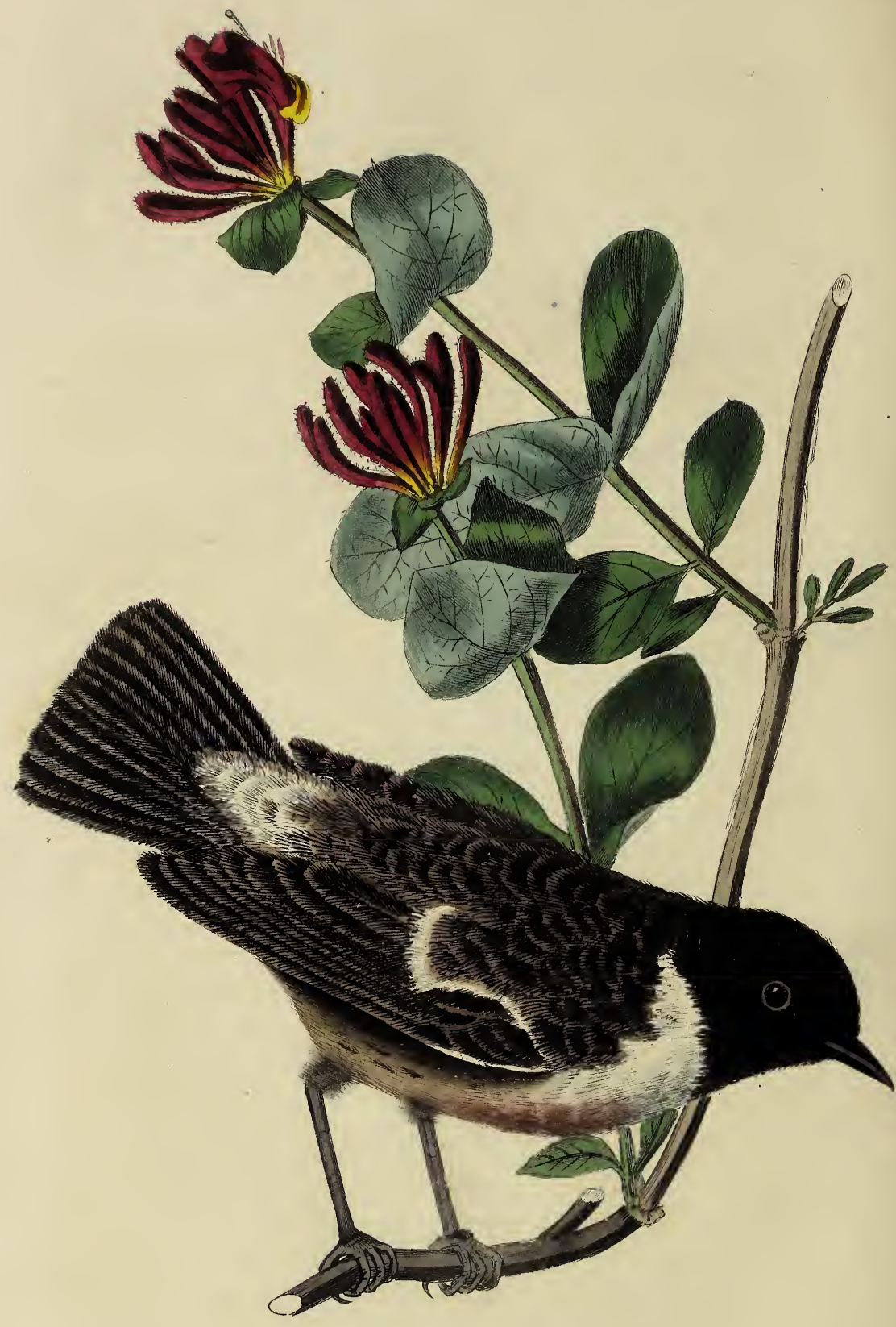




\section{6}

\section{SYLVIA rubicola.}

\section{The Stone-Chat.}

S. rubicola. Deep tawny spotted with black, beneath dull rufous, throat black, side of the neck and spot on the wings white. Turt. Brit. Faun. v. 1. p. 46.

Saxicola rubicola. Beckstein. Temminck man. d'orn. v. 1. Linn. trans. v. 15. p. 20.

Bill black. Iris dusky. Head and throat of the male black; each side of the neck a broad band of white. Quill and tail-feathers dusky, with tawny edges. Rump of the male white. Belly pale rufous, under the tail whitish. Legs black. Tail often moving up and down, and spread out at the same time.

Length five inches and a half; extent near nine; weight half an ounce. Turt. loc. cit.

THE present species, as well as S. rubetra, and S. Enanthe, have, with some other exotic species, been formed into a separate genus by most late authors, which has been named Saxicola by Beckstein, and OEnanthe by Vieillot; but as the name OEnanthe is already occupied with a genus of Umbelliferous plants, Beckstein's name must of course be adopted ; we prefer giving them at present under Sylvia, as hereafter there will require to be several other genera separated from that genus, and the British species proposed by Mr. Vigors, to which it is to be limited, will consist of S. hippolais, S. Trochilus, and S. sylvicola.

The birds of this species, when wild, are generally found on, or near, heaths and commons, frequenting the same places as the Whinchat, but they are not so tender as that bird, as some of them remain in this country all the Winter; they are very variable in their colours, scarcely any two to be seen exactly alike, some of them being nearly all white, others having a large white patch on the wings and by the side of the neck, while others have it very slightly; the brightness of 
their colour also varies considerably on different birds, some of them being particularly handsome.

In confinement this species requires the same food and treatment as the Nightingale, bruised hemp-seed and bread mixed up together into a moist paste; and some fresh, raw, lean beef, or mutton, cut in pieces small enough for them to swallow, is to be mixed with it, for I find they like the meat much better when soaked in the bread and hemp-seed, or if only soaked in clean water, than they do when not soaked at all; besides this I always have an egg boiled quite hard every day; it is then cut in two, and the yolk stirred up in each half, and put in the cages, so that they may peck it out of the shell themselves; this is a change of food for them which keeps them in health; whereas if it was mixed up with other food, it would not be a change, and would not do them half the good; one egg with the other food, is sufficient for twenty birds for one day. The more insects they have given them, the better will be their health, and the more they will sing; they will feed on a great many sorts, and when in a wild state they scarcely eat any thing besides; any sorts of flies, moths, butterflies, caterpillars, maggots, woodlice, earwigs, grasshoppers, crickets, cockroaches, ants, or small beetles, they are very fond of, and numerous other sorts.

In confinement this bird will sing all through the Winter, and a great part of the year ; it will also sing frequently by night as well as by day; it has a very pretty and loud song, and when in confinement its song is continued for a good length of time, not continually broken off in short notes, like the wild ones. If bred up from the nest, I have no doubt but it would learn the notes of other birds, or even any tune that was played to it, as I believe will the greater part of this tribe, if a little pains be taken with them. I have at present a young Whinchat, that was reared by hand from the nest last Summer, and now, in the middle of December, it sings all day long, and a great part of the night, singing the notes of the Whitethroat, Redstart, and the female Willow-Wren, and almost every other note that it hears. 
ADDITIONAL REMARKS, on some of the species that have occurred to the Author, since the publication of the first Parts of the Work.

I BELIEVE it has not been mentioned by any previous Author, that the birds of this genus moult, or change their feathers, more or less, twice in the year; in the Summer or Autumn before they take their departure from this country, and again the latter end of Winter, or before their arrival in Spring; this appears to be a provision of Nature, that their feathers may be fresh and strong, to assist them in their flight from one country to another; I seldom find that they suffer any inconvenience from moulting, as birds in general are supposed to do ; the only thing to guard against, is, to be careful that they do not get chilled with cold, but to keep them rather warmer at that time than they generally are; I find nothing of more real benefit to them, than to place them out in the sun as often as possible, which brings out their feathers very quick.

Those birds are sometimes troubled with warts, or swellings on their feet, particularly in cold weather, which makes them lame, and sometimes it irritates them so much, probably from its itching, that I have known them pull off their claws ; but this is easily remedied, for when they are first observed to be lame, if a little fresh butter be rubbed on their feet, or, what is a great deal better, a small quantity of Price and Gosnell's Cold Cream, will cure them almost immediately. I have cured them in a very short time, even when their feet have been swelled very much, and full of knots or warts. If by accident they happen to break off a claw or toe, it is best to soak it directly in Freeman's Bathing Spirits, which stops the blood immediately, and soon heals the wound. 
I also find that their general food, which is bruised hemp-seed and bread, is apt to become dry on a Summer's day, particularly if the cages are placed out of doors; it must then be moistened, or the birds will not eat it, as they always prefer it very moist ; it had better be a little over-moist than too dry. I also find that they are fondest of their meat, when mixed up with the bruised hemp-seed and bread, which should be cut up in small pieces, not scraped with a knife as is generally done; a little very fresh might be given occasionally, which they will sometimes prefer as a change; the change of food I consider of the greatest importance, both as to keeping them in good health, and raising their spirits to make them sing; nearly the whole of mine have been in full song all the Winter; the greater part began to sing in October, and the others in November.

Bird-Fanciers generally keep their Nightingales, or other birds that they consider tender, in a close cage, with wires only in front, thinking it will keep them warm, and preserve their health; on the same principle I had my largest cage made, only with green baize at the top, to keep them from injuring their heads when on their passage; at the same time $I$ had a less cage, wired all round except on one side, and I was surprized to find that the birds were always more healthy in that, than in the close one, where some of them were frequently ill; and I generally found that when removed into the open cage, they soon recovered: I therefore had the close one altered last Spring, with wires at both ends and front, and a close back, that there might be a free circulation of air, which I supposed the birds wanted, and since that time they have all been in excellent health; I had observed before that, that the Nightingales always sung better in an open cage, than in a close one.

In the beginning of the work I mentioned that a pan of water should be kept continually in their cage, that they might wash whenever they chose; this is the case with the greater part of them when old birds, but it is very hurtful to young ones, as it is apt to give them 
the cramp, and weaken them. I also find that the Wood-Wren, Grasshopper Warbler, Sedge Warbler, and Reed Warbler, will wash so much in Winter, if the water is left continually in their cage, that it will weaken them very much, and frequently cause their death. It is, therefore, best to give them water in something that they cannot wash in, allowing them to wash about once a week in the Winter, and that always in the morning of a fine day; they will then be able to clean and dry themselves in good time.

In a letter from the Honourable and Reverend William Herbert, he informs me, that, " two years ago, he saw beside a green lane, near Highclere, in Hampshire, a pair of Sylviadece in May, shaped like the Whitethroat, but nearly as large as a Nightingale, the under parts of a glossy ashy-whiteness, rather whiter than the belly of the Larger Whitethroat; upper parts entirely rufous, with a dark streak over the eye; they lighted frequently either on the fence, or on some of the lower branches of some Oak-trees, close to the fence, not concealing themselves, but continuing exposed to the sight, and remaining long in the same posture." From the above account, I believe it to be a species, that I observed plentiful one Summer, a great many years since, in the gardens of Richard Bright, Esq. of Hamgreen, near Bristol, where they came to feed on the fruit and insects, particularly on the Raspberries ; they always came in with great velocity, and generally several together, and were rather more shy than the Blackcaps, and other Warblers that were feeding there at the same time. I did not happen to catch either of them, nor was I particular about them at that time, not supposing but they were regular, or, at least, frequent visitors, but I have never seen one of them since that season.

S. Rubetra, or Whinchat. T'bis species, and the Redstart, I find to be the most tender of any of the sorts that I have kept through the Winter, but they may be managed very well, by keeping them in a warm room in cold frosty weather. One that I possess at present is the most interesting bird $\mathbf{I}$ have; it was taken from 
the nest last Summer on Wandsworth Common, and bred up by hand, by which means it became very tame and bold; when young, it was seized with the cramp, which I thought might be occasioned by the want of sand or gravel, as I suspect what they eat of that turns to lime, and forms or hardens their bones. I accordingly mixed up some small stones, about the size of small shots, in its food, after it had not been able to stand for three or four days; the first day I gave it him, he became much stronger, and could stand a little before night ; the next day it was quite well, and could jump up and down the perches as if nothing had ever ailed it, and it has continued in good health ever since, and is now as handsome a bird as need be; it has been in full song ever since last October, singing nearly the whole day through, and very often at night; its song is now very loud and very variable, as it has learnt the songs of most of the other birds. In my account of the Stonechat, I mentioned this bird as having learnt the song of the Larger Whitethroat, the Redstart, and the female Willow-Wren; since that it has learnt the song of the Missel-Thrush, which it hears in the garden near by ; it also learnt the Nightingale's jug, jug, jug, and repeated it in five minutes after hearing the Nightingale sing, and it now sings it frequently, so that it is impossible to know which of the two are singing without seeing them. The same treatment is required for breeding those birds from the nest, as I have already mentioned in treating of some of the other species; and afterwards, to keep them in good health, give them as many insects as possible, such as the common maggots, small beetles, cockroaches, crickets, grasshoppers, and almost all sorts of small insects.

S. Phonicurus, the Redstart. I have now a beautiful male bird of this species, which I have possessed for six years; it always keeps itself in as good health, and in as fine a plumage, as if flying wild in the open air, continuing in song the greater part of the year. It is certainly the most sensible and cunning species of the tribe, and becomes very much attached to any person who notices it ; mine flew out of its cage, about two 
years since, and got away into the gardens, where it continued six or seven hours; it then returned to its cage, although it was a wild bird when first caught. In the year 1825 I saw a female of this species so late as the 21st of November, in Camera Square, Chelsea, flying about as lively as if it had been Midsummer.

S. Luscinia, the Nightingale. Since I published my account of this species, I have had a female which built a nest in the cage, in a little work-basket, put in on purpose; she laid three eggs, and sat on them till she was almost starved, as the male bird would not feed her; she then threw the eggs out, and broke them; both the male and female were only one year old birds; and 1 have no donbt but they would have bred in confinement, had they been kept together another season; but I parted with the female to a gentleman who particularly wished it. I have since had a female several years, but it has never attempted to build, which I believe is owing to its being an old bird when first caught: some authors give it as their opinion that the female of this species sings, but I have never heard one make the least attempt, though I have frequently kept them several years.

S. hortensis, the Greater Pettychaps. This species builds its nest on trees or high shrubs, from ten to twelve feet above the ground; it is generally very deep, but thin, and composed of dry grass. It is not so tender as I formerly supposed; one that I have now kept nearly six years, never seems to mind the cold at all. I have kept females of this species, and also of both species of Whitethroats, for several years, but none of them ever attempted to sing.

S. cinerea, the Larger Whitethroat. I have now a fine male bird of this species, that I have possessed between eight and nine years, the same from which the drawing was made for the first part of this work; it still continues as lively, and sings as well as ever; it is a very desirable species, as it never seems to mind the cold, and continues in song nearly all the year.

S. Trochilus, the Willow Wren. This is also a very desirable bird, as it continues in song the greater part 
of the year, and its song is so loud and shrill, that it may be heard above that of any other birds. I also possess a female of it that sings frequently, but her note is very different from that of the male. The Honourable and Reverend William Herbert observes that " it ought to be mentioned, that Gardeners are in the habit of cruelly destroying the nests of this bird, confounding it with the Greater Pettychaps, and imagining that they attack the Cherries; whereas it never touches fruit, but is the Gardener's friend, picking the Aphides from the trees with great industry." This is the case with several other species, the Gardeners confounding them altogether under the common appellation of Whitethroats, and destroying them indiscriminately ; whereas it is only the Greater Pettychaps and the Blackcap that materially injure the fruit; but as the Blackcap has not a black head the first season, it is not in general distinguished from the Whitethroats.

S. Sylviella, the Lesser Whitethroat. This elegant little bird is well worth keeping in confinement. I have at present a very handsome one, which is continually singing, and has a very pleasing soft note, much more pleasant than the wild ones; they soon become much attached to their cage, and to the person who feeds them.

S. atricapilla, the Blackcap. The female of this species sings in confinement, but its note is quite different, and not so agreeable as the male. It has now been in my possession nearly six years; the three first years it did not sing, but since that time it sings frequently. 


\section{SYLVIA arundinacea.}

The Reed-Wren, or Reed-Warbler.

S. arundinacea. Above olive-brown, beneath yellowishwhite, lores and orbits whitish-brown, wings with a tawnyyellow band in the middle underneath, tail brown somewhat wedge-form. Turt. Brit. Faun. v. 1. p. 45.

Bill dusky above, yellowish beneath, broad at the base. Iris hazel. Sides inclining to rufous brown. From the bill to the eye a lightish streak. Quill and tail-feathers dusky, with olive-brown margins. Legs dusky. Soles greenish-yellow.

Length hardly five inches and a half; weight about three drachms. Turt. loc. cit.

\section{1}

\section{SYLVIA sylvicola.}

\section{The Wood-Wren.}

S. sylvicola. Yellow-green, throat and cheeks yellow, belly - pure white, from the bill over the eye a bright brimstone streak.

Sylvia sylvicola. Linn. trans. 4. p. 245. t. 24.

Sylvia sibilatrix. Beckstein.

Bill dusky. Iris hazel. Through the eyes a bright sulphur streak, but not under them as in S. Hippolais. Upper part of the breast yellowish-white. Quill-feathers dusky, edged on the outer webs with yellow-green. Tail-feathers dusky, edged with green on the outer webs except the first, and with white on the inner. Legs horn-colour.

Length five inches and a quarter; weight near three drachms. Turt. Brit. Faun. v. 1. p. 44. 


\section{2}

\section{SYLVIA Locustella.}

\section{The Grasshopper Warbler.}

S. Locustella. Olive-brown with dusky spots, beneath yellowish-white darker on the breast, tail wedge-shaped with pointed feathers. Turt. Brit. Faun. v. 1. p. 45.

Bill dusky above, pale beneath. Iris hazel. From the bill to the eyes a yellowish streak. Breast and sides inclining to brown, with a few dark streaks. Quills and tail dusky olive-brown with paler outer margins. Legs pale brown.

Length five inches and a half; weight three drachms and a quarter. Turt. loc. cit.

\section{3 \\ SYLVIA salicaria. \\ The Sedge Warbler.}

S. salicaria. Yellowish-brown with dusky spots, beneath dirty white, tail-coverts pale tawny, over the eye a white stripe. Turt Brit. Faun. v. 1.p. 46.

Bill black, pale beneath. Cheeks pale brown ; over the eyebrows a black stripe. Breast and sides darker. Quills and tail dusky, the former edged with olive-brown. Tail a little wedge-form. Iegs dusky. Turt. loc. cit. 


\section{SYLVIA Dartfordiensis.}

The Dartford Warbler.

S. Dartfordiensis. Deep rufous brown, beneath ferruginous, belly white in the middle, iris and eye-lids red, legs yellow. Turt. Brit. Faun. v. 1. p. 46.

Bill black, whitish at the base of the upper mandible. Throat with a few whitish spots. Cheeks dark grey. Quills dusky, edged with dark grey. Spurious wing white. Tail wedgeform, brown, the outmost feathers white on the outer edge. Turt. loc. cit.

\section{5}

\section{SYLVIA rubicola.}

The Stone-Chat.

S. rubicola. Deep tawny spotted with black, beneath dull rufous, throat black; side of the neck and spot on the wings white. Turt. Brit. Faun. v. 1. p. 46.

Bill black. Iris dusky. Head and throat of the male black; each side of the neck a broad band of white. Quill and tailfeathers dusky, with tawny edges. Rump of the male white. Belly pale rufous, under the tail whitish. Legs black.

Length five inches and a half; extent near nine; weight half an ounce. Turt. loc. cit.

This species is occasionally seen in Winter. 


\section{6}

\section{SYLVIA Enanthe.}

\section{The Wheat-Ear, or White-Rump.}

S. Enanthe. Head and back bluish grey, cheeks black, over the eyes a dirty white stripe, breast and belly yellowishwhite, rump and base of the tail white. Turt. Brit. Faun. v. 1. p. 46 .

Bill black. Iris hazel ; from the bill a black stripe, forming a black patch round the eyes. Front dirty white. Wings and coverts dusky, with reddish brown edges. Breast with a reddish tinge, under the tail white. Two middle tail-feathers white with a black base, the rest white tipt with black. Legs blackish.

Length above six inches; extent near twelve; weight near seven drachms. Turt. loc. cit.

Besides the species here enumerated, there are four others which remain in Britain all the year. The Hedge-Sparrow (S. modularis;) the Red-breast (S. rubecula;) the Wren (S. Troglodytes;) and the Golden-crested Wren (S. Regulus.)

Note. The birds of this genus are sometimes troubled with Worms. A White-throat that I caught last Summer, always had a rough appearance, although it fed heartily; it continued to look worse till about Christmas, when it died. I immediately cut it open, and found its inside full of living Worms; I believe of the genus Trenia; they were from one to three inches long; blunt at one end, and tapering to a very fine point at the other; slightly flattened; the joints very near to each other; each about three times broader than long. 





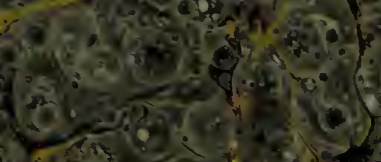

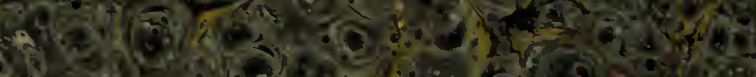

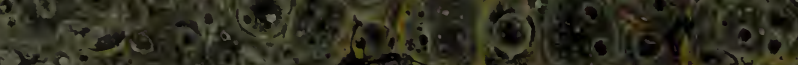

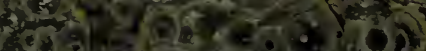

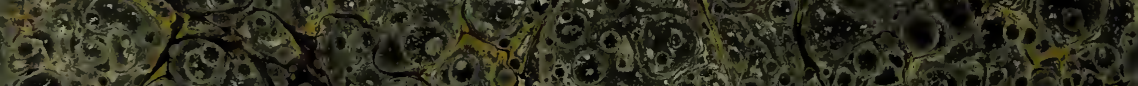

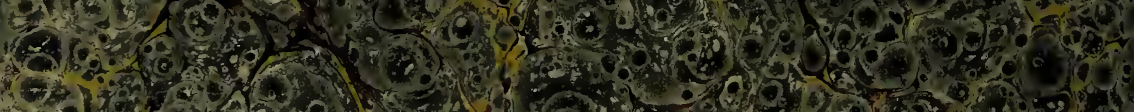

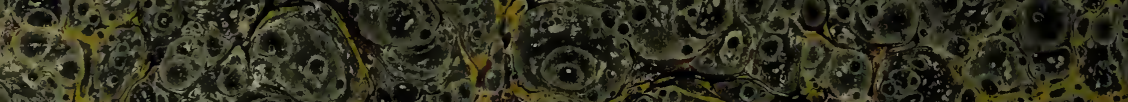

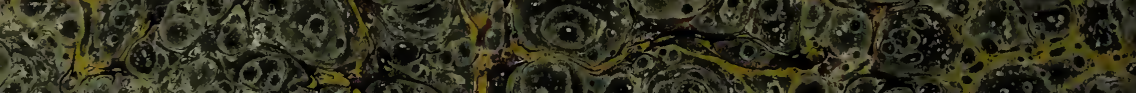

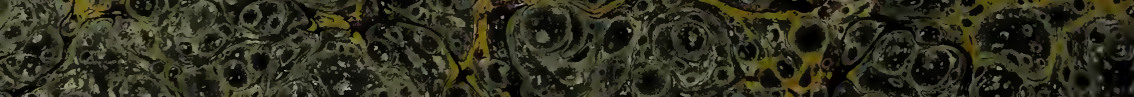

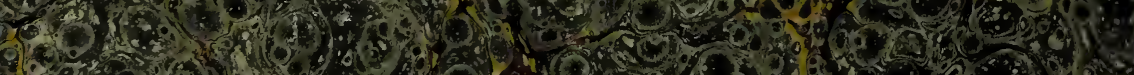

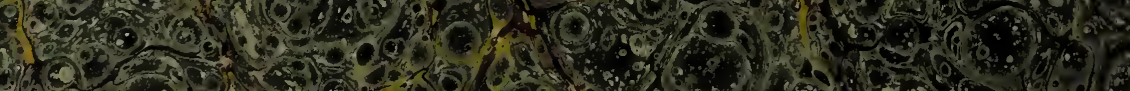

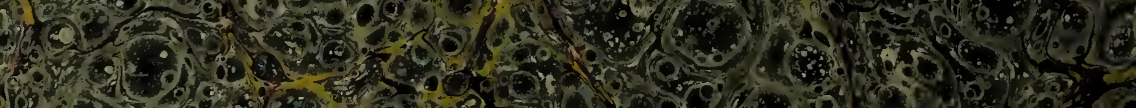

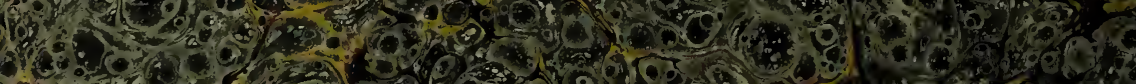

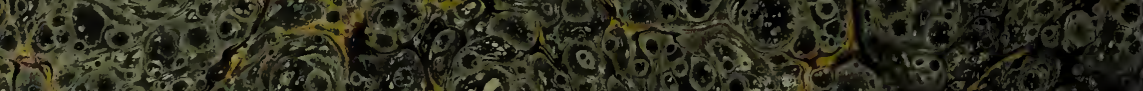

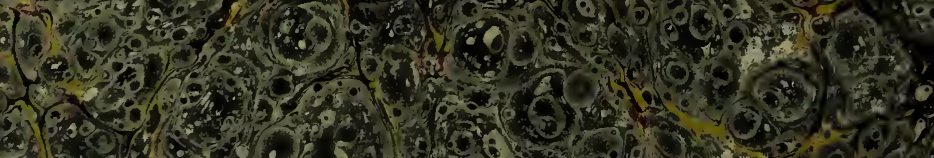

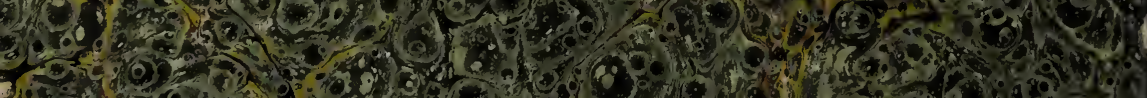

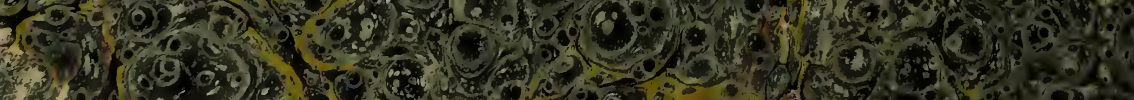

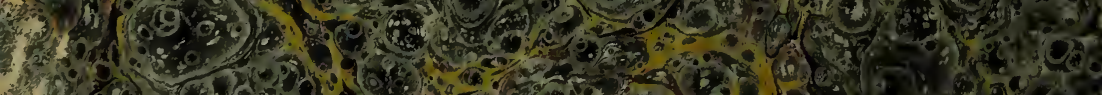

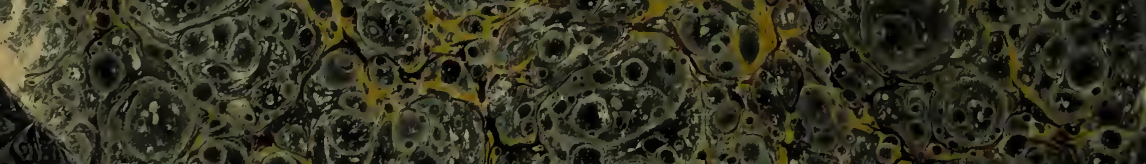

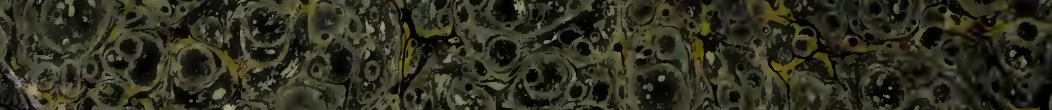

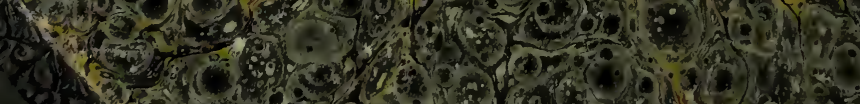

